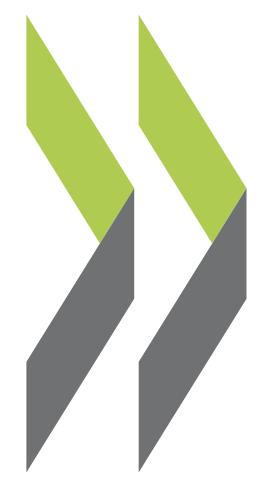

OECD Economics Department Working Papers No. 1409

Sharing the benefits of China's growth by providing opportunities

\title{
Ben Westmore
}

to all 
Organisation de Coopération et de Développement Économiques

Organisation for Economic Co-operation and Development

06-Sep-2017

ECONOMICS DEPARTMENT

English - Or. English

SHARING THE BENEFITS OF CHINA'S GROWTH BY PROVIDING OPPORTUNITIES TO ALL

ECONOMICS DEPARTMENT WORKING PAPERS No. 1409

By Ben Westmore

OECD Working Papers should not be reported as representing the official views of the OECD or of its member countries. The opinions expressed and arguments employed are those of the author(s).

Authorised for publication by Alvaro Pereira, Director, Country Studies Branch, Economics Department.

All Economics Department Working Papers are available at www.oecd.org/eco/workingpapers.

Complete document available on OLIS in its original format

This document, as well as any data and map included herein, are without prejudice to the status of or sovereignty over any territory, to the delimitation of international frontiers and boundaries and to the name of any territory, city or area. 
OECD Working Papers should not be reported as representing the official views of the OECD or of its member countries. The opinions expressed and arguments employed are those of the author(s).

Working Papers describe preliminary results or research in progress by the author(s) and are published to stimulate discussion on a broad range of issues on which the OECD works.

Comments on Working Papers are welcomed, and may be sent to OECD Economics Department, 2 Rue André-Pascal, 75775 Paris Cedex 16, France, or by e-mail to eco.contact@oecd.org.

All Economics Department Working Papers are available at. www.oecd.org/eco/workingpapers.

This document and any map included herein are without prejudice to the status of or sovereignty over any territory, to the delimitation of international frontiers and boundaries and to the name of any territory, city or area.

The statistical data for Israel are supplied by and under the responsibility of the relevant Israeli authorities. The use of such data by the OECD is without prejudice to the status of the Golan Heights, East Jerusalem and Israeli settlements in the West Bank under the terms of international law.

Latvia was not an OECD Member at the time of preparation of this publication. Accordingly, Latvia does not appear in the list of OECD Members and is not included in the zone aggregates.

\section{(C) OECD (2017)}

You can copy, download or print OECD content for your own use, and you can include excerpts from OECD publications, databases and multimedia products in your own documents, presentations, blogs, websites and teaching materials, provided that suitable acknowledgment of OECD as source and copyright owner is given. All requests for commercial use and translation rights should be submitted to rights@oecd.org 


\section{ABSTRACT/RÉSUMÉ}

\section{Sharing the benefits of China's growth by providing opportunities to all}

Living standards in China have greatly improved over the past few decades. Both sustained economic growth and an expansion of the social security system have contributed to a sharp reduction in the number of people in poverty. However, urban-rural inequalities remain large and some of the poorest households are being left behind. Further reforms are needed to ensure that the benefits of future growth are shared and that marginalised groups have the opportunity to actively participate in the economy. In particular, policy settings should be adjusted to increase access to good quality education and healthcare for rural and migrant workers and to improve the portability of social security benefits. Changes to the social assistance system that raise work incentives and protect low-income households in poorer locations are also a priority. New spending measures can be funded by adjustments to the tax system which will, in themselves, benefit inclusiveness.

This Working Paper relates to the 2017 OECD Economic Survey of China (www.oecd.org/eco/surveys/economic-survey-china.htm).

JEL classification codes: H55, I14, I24, I30, I38, O53.

Keywords: China, inclusive growth, social assistance policies, education, health, pension system.

$* * * * * * * * * * * * * * * * * * * * * * *$

\section{Partager les fruits de la croissance de la Chine en offrant des opportunités à tous}

Les niveaux de vie en Chine se sont considérablement améliorés au cours des dernières décennies. La croissance économique soutenue et l'expansion du système de sécurité sociale ont contribué à une forte réduction du nombre de personnes vivant dans la pauvreté. Cependant, les inégalités entre villes et campagnes demeurent importantes et certains des ménages les plus pauvres sont laissés de côté. D'autres réformes sont nécessaires pour que les fruits de la croissance future soient partagés et que les groupes marginalisés aient la possibilité de participer activement à l'économie. En particulier, les cadres politiques devraient être adaptés pour accroître l'accès à une éducation et à des soins de santé de qualité pour les travailleurs ruraux et migrants et pour améliorer la transférabilité des prestations de sécurité sociale. Les changements au système d'aide sociale qui augmentent les incitations au travail et protègent les ménages à faible revenu dans les zones pauvres sont également une priorité. Les nouvelles mesures de dépenses peuvent être financées par des ajustements du régime fiscal qui, en eux-mêmes, amélioreront l'inclusivité.

Ce Document de travail se rapporte à l'Étude économique de l'OCDE de la Chine, 2017 (www.oecd.org/fr/eco/etudes/etude-economique-chine.htm).

Codes de classification JEL: H55, I14, I24, I30, I38, O53.

Mots-clés : Chine, croissance inclusive, politiques d'aide sociale, éducation, santé, système de retraite. 


\section{TABLE OF CONTENTS}

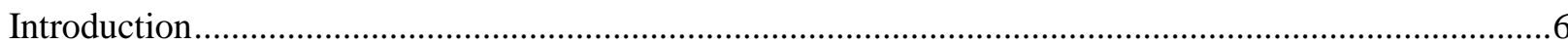

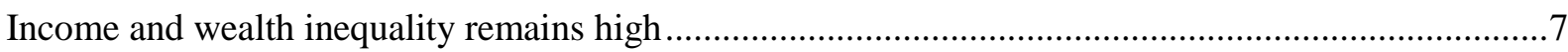

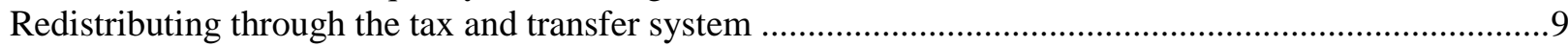

Some aspects of the tax system disadvantage low-income earners.................................................

The social assistance system has increased coverage but may distort work incentives ..........................11

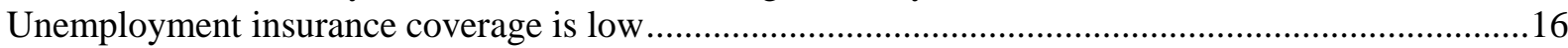

Better targeted poverty-reduction benefits remain necessary .............................................................. 16

Helping low-paid workers improve their productivity and appropriate the rewards ...............................19

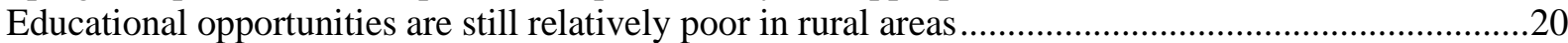

Labour market institutions have been established to promote job quality and fair wages .....................21

Labour market opportunities for some groups are reduced by policy distortions ..................................23

Improving the health system to enhance living standards ..................................................................27

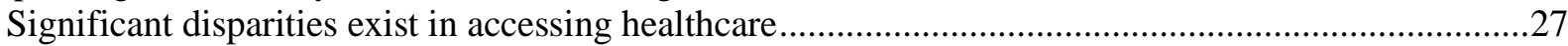

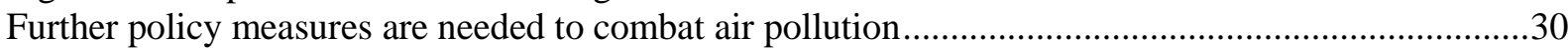

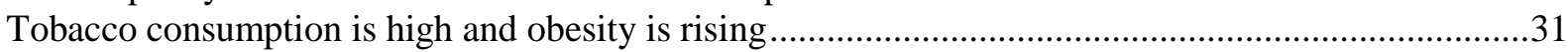

Extending the working lives of the elderly and caring for them in retirement ........................................

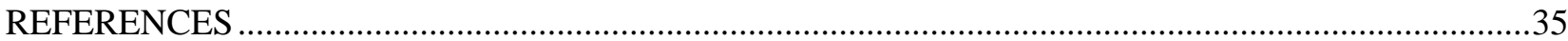

\section{Tables}

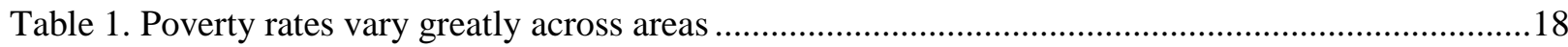

Table 2. The impoverished in most regions spent more of their income on health and housing ...............19

Table 3. Migrant workers have limited access to public services ...........................................................25

\section{Figures}

Figure 1. The share of the working age population is shrinking ............................................................6

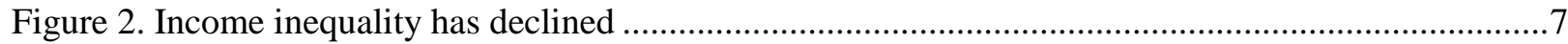

Figure 3. The income share of the poorest people is low and has been falling in rural areas.....................8

Figure 4. Redistribution by the tax and transfer system is very limited ................................................

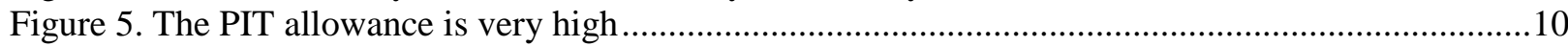

Figure 6. The coverage of the dibao programme has peaked in both urban and rural areas ....................12

Figure 7. The minimum living standard varies significantly across provinces........................................13

Figure 8. Minimum income thresholds vary greatly within provinces ..............................................14

Figure 9 Impoverished households spent more of their income on health and housing ..........................19

Figure 10 .Socioeconomic factors have a large influence on Chinese PISA scores .................................21

Figure 11. Minimum wages are low compared with OECD countries ...............................................23

Figure 12. A large share of migrant workers do not have labour contracts ...........................................24

Figure 13. The employment share in agriculture is higher for women .................................................26

Figure 14. The availability of healthcare is much lower in rural areas.............................................28

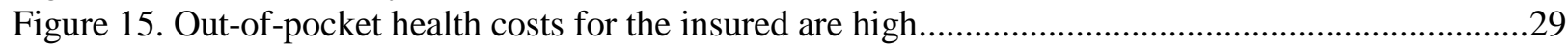

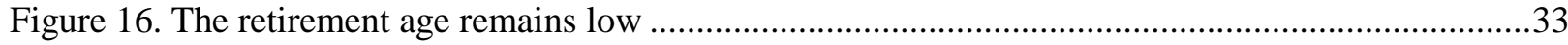


ECO/WKP(2017)41

\section{Boxes}

Box 1. Variation in China's Minimum Income Threshold ....................................................................14

Box 2. The impoverished households in five Chinese administrative regions .......................................18

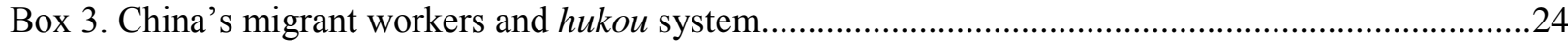

Recommendations for sharing the benefits of growth by providing opportunities to all..........................33 


\title{
SHARING THE BENEFITS OF CHINA'S GROWTH BY PROVIDING OPPORTUNITIES TO ALL
}

\author{
by Ben Westmore ${ }^{1}$
}

\section{Introduction}

China's economic performance over the past few decades has been remarkable, but has been accompanied by rising inequality. The goal of the Chinese government to achieve a "moderately prosperous society in all respects" by 2020 emphasises a strong commitment to improving social welfare throughout the population, and to eradicating poverty one decade ahead of the United Nations Sustainable Development Goals deadline. This can be achieved by pursuing inclusive growth, a concept that focuses on sharing the benefits of increased prosperity across socioeconomic groups that goes beyond just monetary conditions to consider other aspects of wellbeing. At the same time, a more equitable distribution of the benefits of economic growth should support the rebalancing of the economy to a more consumption-based growth model.

Figure 1. The share of the working age population is shrinking Projected proportion of $65+$ age population to the $15-64$ age population

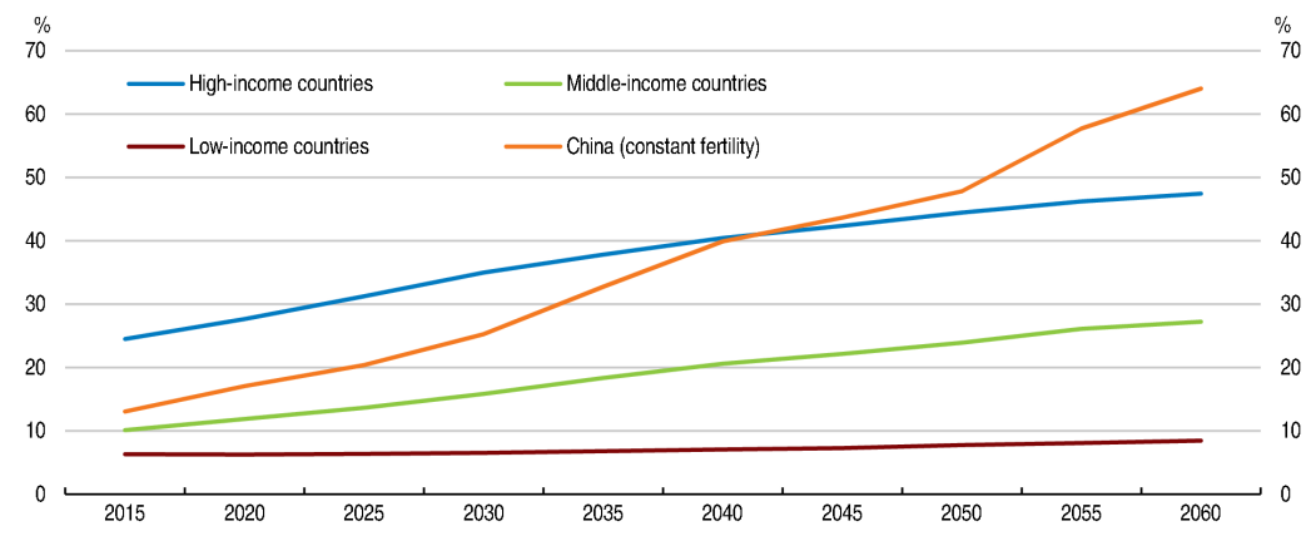

Note: Projections for China are shown under a constant-fertility assumption of 1.55 children per woman.

Source: United Nations World Population Prospects, the 2015 Revision.

Improvements in living standards for some marginalised groups are also vital to the supply-side of the economy. Although old-age dependency varies significantly across provinces (OECD, 2015a), China is facing a much steeper increase in the share of the elderly-to-working-age population in the coming decades than most other economies (Figure 1). Any pick-up in the fertility rate that may result from the recent relaxation of the One-Child Policy will only slightly mitigate this trend. With such significant demographic

1 Ben Westmore (ben.westmore@oecd.org) is a member of the OECD Economics Department. The author would like to thank Margit Molnar, Vincent Koen, Alvaro Pereira, Robert Ford, Jiangyuan Lu, Orsetta Causa and Isabelle Joumard from the OECD Economics Department, Paulo Falco, Willem Adema, Michele Cecchini and Akiko Maeda from the OECD Directorate for Employment, Labour and Social Affairs; Irène Hors, Chan Yang, Jingjing Chen and Yan Li from the OECD General Secretariat and Bert Brys from the OECD Centre for Tax Policy and Administration for valuable discussions and feedback on earlier drafts. The paper also benefitted from the comments of officials from the Chinese government. Special thanks to Thomas Chalaux and Hyunjeong Hwang for statistical support and Mercedes Burgos and Sisse Nielsen for editorial assistance, all from the OECD Economics Department. 
pressures, it is critical that all members of society have the opportunity to fulfil their potential and make a productive contribution.

\section{Income and wealth inequality remains high}

Income inequality, as officially measured by the Gini coefficient, has declined since 2008 after rising to a very high level in the years before (Figure 2, Panel A). This partly reflects a decline in the urban-rural income gap, a major source of income inequality in China (Panel B). The narrowing of the urban-rural divide has been most notable within the Western part of the country, but has been observable across all regions.

Within the urban and rural economies, there has also been some income convergence. Urban incomes in central, western and north-eastern regions have caught up with urban incomes in the east (Figure 2, Panel C). Similarly, rural incomes in central, western and north-eastern regions have grown relatively fast (Panel D). In part, this is a legacy of various government projects launched in the early 2000s including the Northeast China Revitalization Campaign, the Rise of Central China Plan and the Western Development Plan.

Figure 2. Income inequality has declined
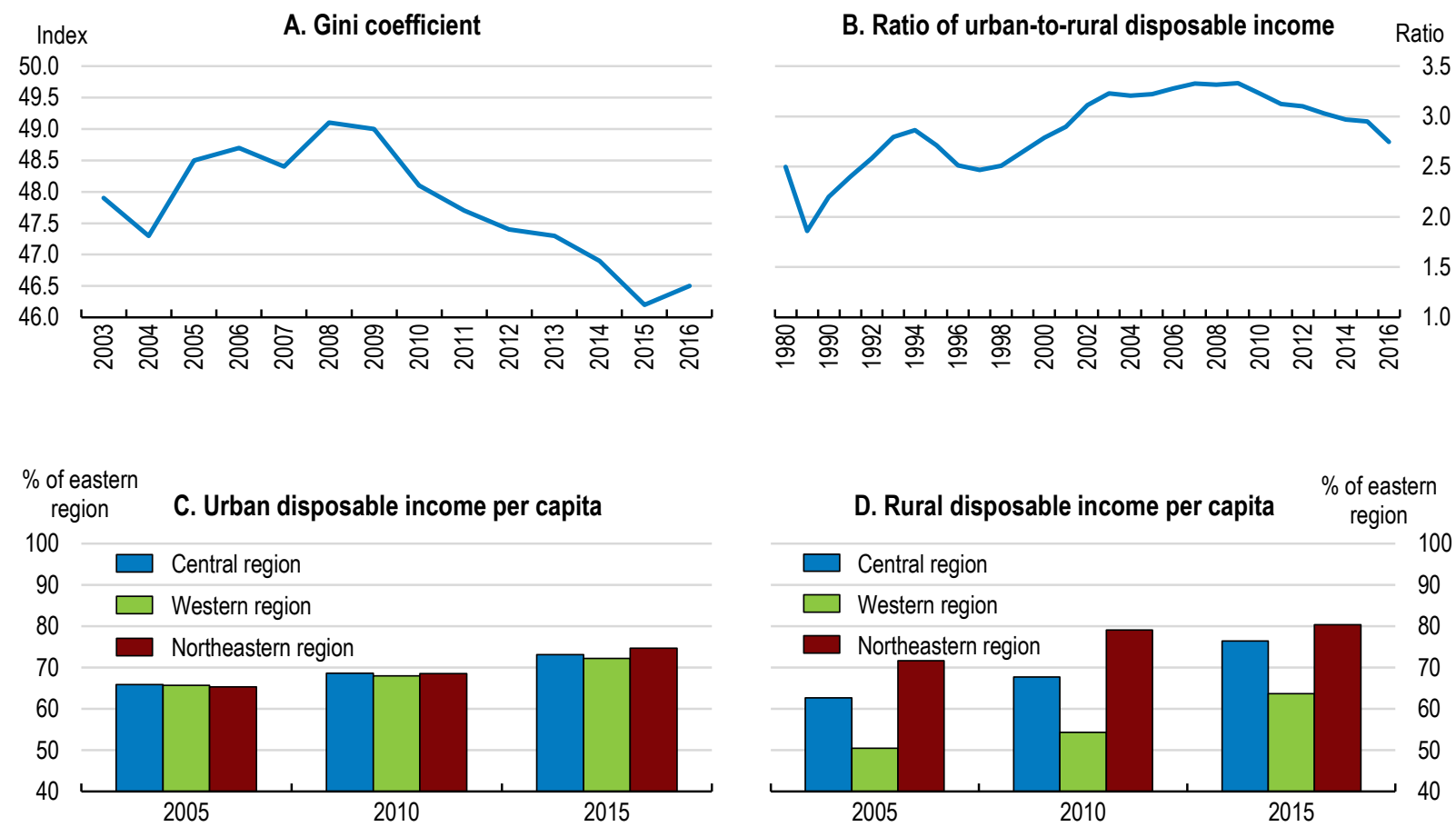

Note: The Gini coefficient presented here is based on income and has a range from zero (when everybody has identical incomes) to 100 (when all income goes to only one person). Increasing values of the Gini coefficient thus indicate higher inequality in the distribution of income.

Source: China National Bureau of Statistics, authors' calculations.

Despite the reduction in aggregate income inequality, many of the poorest households have been falling behind. There has been relatively strong growth in the middle part of the income distribution, matching the experience of many other emerging countries through the era of globalisation (Milanovic, 2016). However, the gap between the richest and poorest urban households in terms of disposable income 
has barely narrowed. In rural areas, it has even widened: in 2005, the richest $20 \%$ of rural households had an income share that was 7.3 times higher than the poorest $20 \%$, but by 2015 , the ratio had increased to 8.4 (Figure 3, Panel A). This was principally due to the sluggish income growth of the poorest $20 \%$. The ratio is even higher when considered nationwide, at 10 in 2015 - significantly above most other countries for which recent data are available (Panel B). High relative income inequality has been reflected in measures of life satisfaction. While such indices are fraught with measurement issues, Easterlin et al. (2013) find that since 1990 life satisfaction has declined for Chinese people in the bottom third of the income distribution and increased for those in the top third.

\section{Figure 3. The income share of the poorest people is low and has been falling in rural areas}

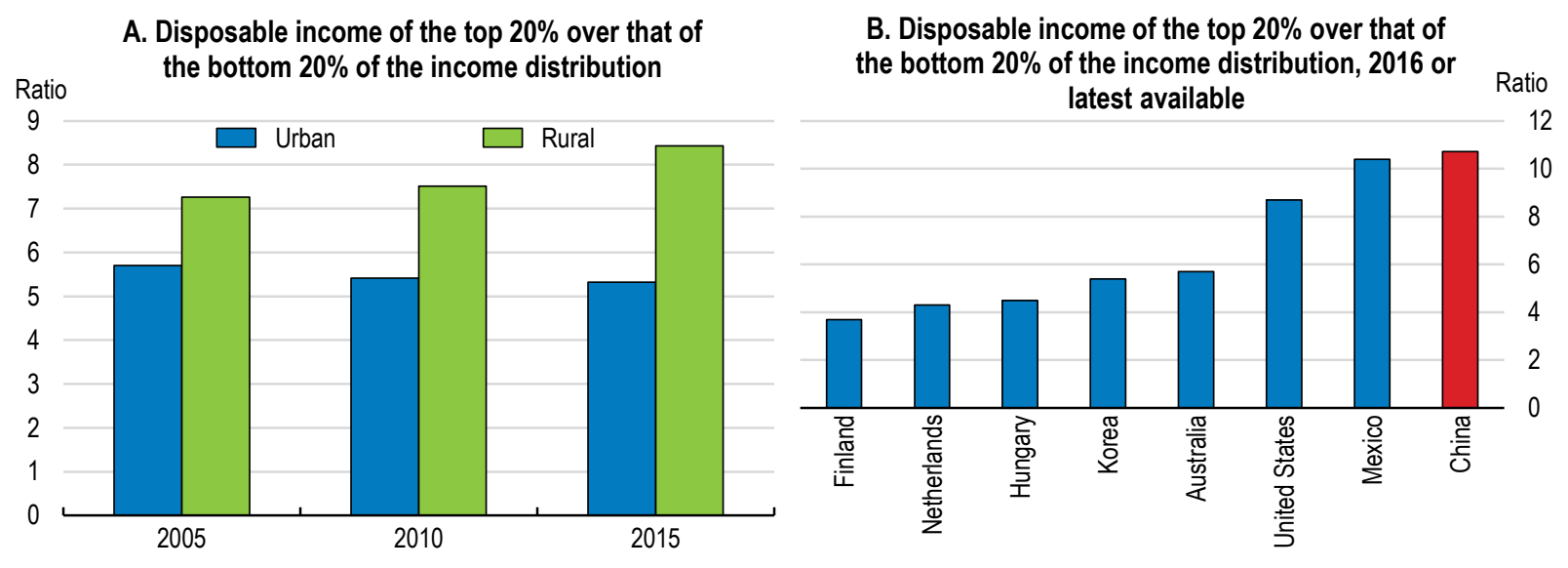

Note: In Panel B, data for China are for 2016, but data for all other countries are for 2014 (the latest available observation). Incomes are not equivalised and, while conceptually identical, the data for China and the other countries presented in Panel B are from different sources.

Source: China National Bureau of Statistics, OECD Income Distribution Database.

Over the past two decades, the share of wealth held by the top segment of the income distribution has been rising (Xie and Jin, 2015). Recent analysis using household data suggests that the Gini coefficient for total wealth rose from 0.45 in 1995 to 0.73 in 2013, at which time the top $1 \%$ of the population held onethird of total assets (Peking University, 2014). Such a surge in wealth disparity contrasts with the trend in the Gini coefficient for income presented above and signals a weakening in intergenerational mobility which is detrimental to both economic growth and equity (Cingano, 2014). The increase in wealth inequality over this period partly reflects the impact of reforms that transferred housing assets from state to private ownership, combined with disparities in housing values across locations.

Notwithstanding the wide gap between the richest and poorest, poverty has declined substantially: the share of the rural population living below the poverty line (as measured by the current rural poverty threshold of CNY 2300 per capita net income in 2010 prices) fell from $30 \%$ in 2005 to $5.7 \%$ in 2015. This reflected China's strong economic growth and improvements in the social welfare system. By the end of 2016, there were 43.3 million rural people still in poverty. The government is aiming to lift all of these above the current poverty line by 2020 .

The marked reduction in poverty without the lowest income quintile gaining income share suggests that while many households have been lifted above a subsistence level, there has been less success in creating the necessary conditions to encourage further growth in the incomes of the lowest earners. The tax and transfer system, labour market institutions, as well as education, health and pension systems must all contribute to further lifting people from poverty as well as ensuring that all members of society have the 
opportunity to continue raising their living standards. Subsequent improvements in social mobility will benefit economic growth, especially given the nascent demographic headwinds.

\section{Redistributing through the tax and transfer system}

The overall redistributive impact of the tax and transfer system in China is very low despite relatively high market income inequality (Figure 4). In the past decade, the redistributive potency of taxes and transfers has even diminished (Cevik and Correa-Caro, 2015). This contributes to the large gap in disposable income share between the richest and poorest households highlighted above.

Figure 4. Redistribution by the tax and transfer system is very limited

Reduction in market income inequality due to taxes and transfers, 2013/15

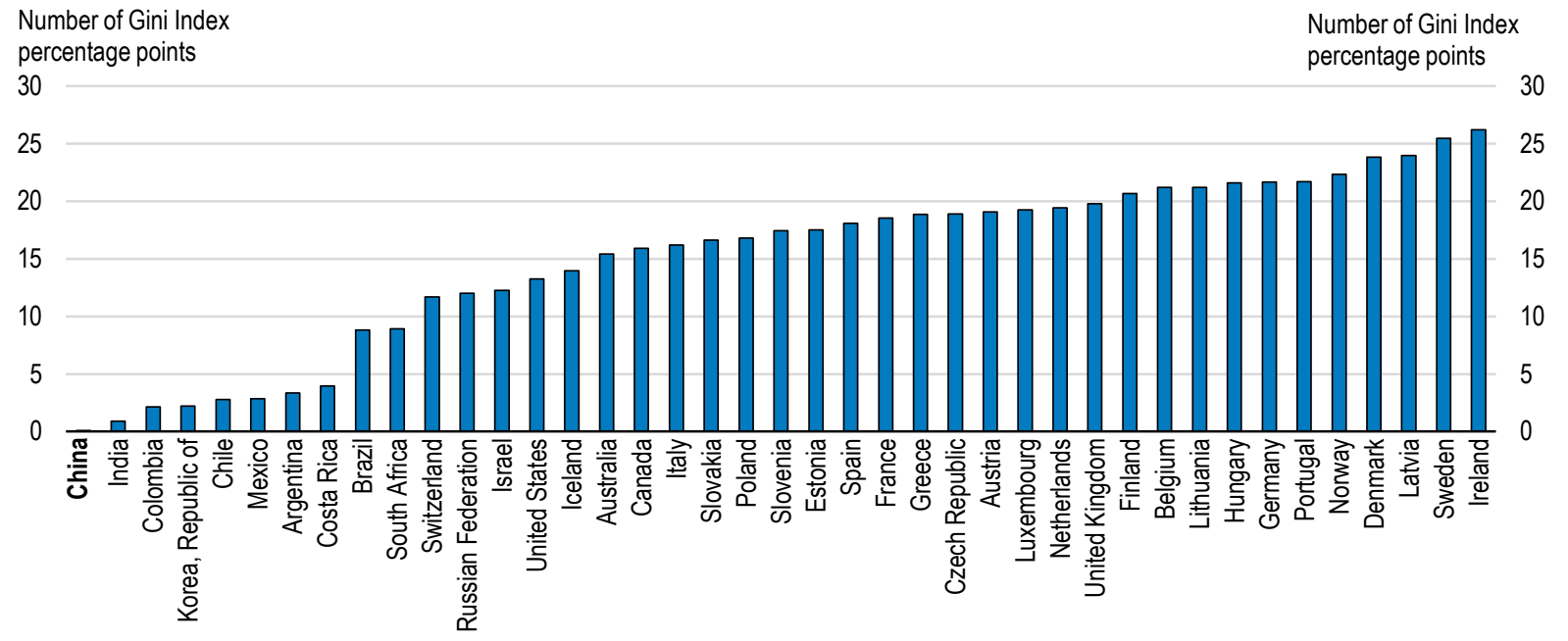

Note: Data for China are for 2013. Data for other countries are the latest available observation (2013 to 2015), with the exception of India (2011) and South Africa (2012). The metric presented here is calculated from data that are standardised to allow cross-country comparisons. Potential remaining comparability issues are detailed in Solt (2016).

Source: Standardised World Income Inequality Database (SWIID) Version 5.1.

\section{Some aspects of the tax system disadvantage low-income earners}

The design of the employee social security contribution scheme is a major factor in the weak redistributive effect of China's tax and transfers system. Social security contributions are made by both employers and employees to fund pensions, medical insurance and unemployment insurance. While the employee contribution is levied as a nominal flat rate, all employees are required to at least make a minimum contribution which is calculated on an imputed value of earnings (irrespective of the employee's actual income) equivalent to $60 \%$ of the previous year's local average wage. Contributions are also capped at the payment required by an individual earning three times the local average wage. As a result, of those households making social security contributions, many in the lowest income quintile pay a much higher share of their income in social security payments than those with higher incomes (Lam and Wingender, 2015).

The requirement for employees to pay a minimum social security contribution irrespective of actual income earned contrasts with the situation in most OECD countries (Brys et al., 2013). Indeed, governments often seek to reduce contribution rates for low-income workers to encourage their 
participation in the formal labour market (OECD, 2011). Workers who are outside the formal labour market (as well as those unemployed or self-employed) are not required to participate in the pension and medical insurance schemes in China, potentially increasing their financial vulnerability to future shocks. To the extent that the existing system encourages low-income workers to seek informal employment, it may also have negative implications for job security and skill accumulation. This can be addressed by reforms that base the calculation of social security contributions of low-income workers on actual income earned. This could be partly financed by reforms to the personal income tax (PIT) system that increase government receipts.

The PIT system currently raises little revenue due to a narrow tax base, which limits its redistributive impact (Brys et al., 2013). In 2016, PIT revenue amounted to 1.4\% of GDP, below those OECD countries with the lowest personal income tax-to-GDP ratios (Chile, 1.5\%; Slovak Republic, 3.2\%; Mexico, 3.4\% and Czech Republic, 3.6\% in 2015).

While the PIT schedule is progressive, there is a very generous allowance for all wage earners equivalent to two-thirds of the average urban wage - so most workers do not pay income tax (Figure 5; Lam and Wingender, 2015). The value of this allowance increases with the taxpayer's marginal PIT rate, meaning it disproportionately benefits richer workers. Furthermore, the tax authorities face challenges in taxing some of the income of the wealthiest individuals, and especially income held overseas. The Ministry of Finance recently established an office dedicated to the much-needed reform of the PIT system and the State Administration of Taxation have now published draft regulations which aim to reduce the scope for cross-border tax avoidance (State Administration of Taxation, 2016).

Figure 5. The PIT allowance is very high

Basic PIT allowance as a \% share of average wage, 2015

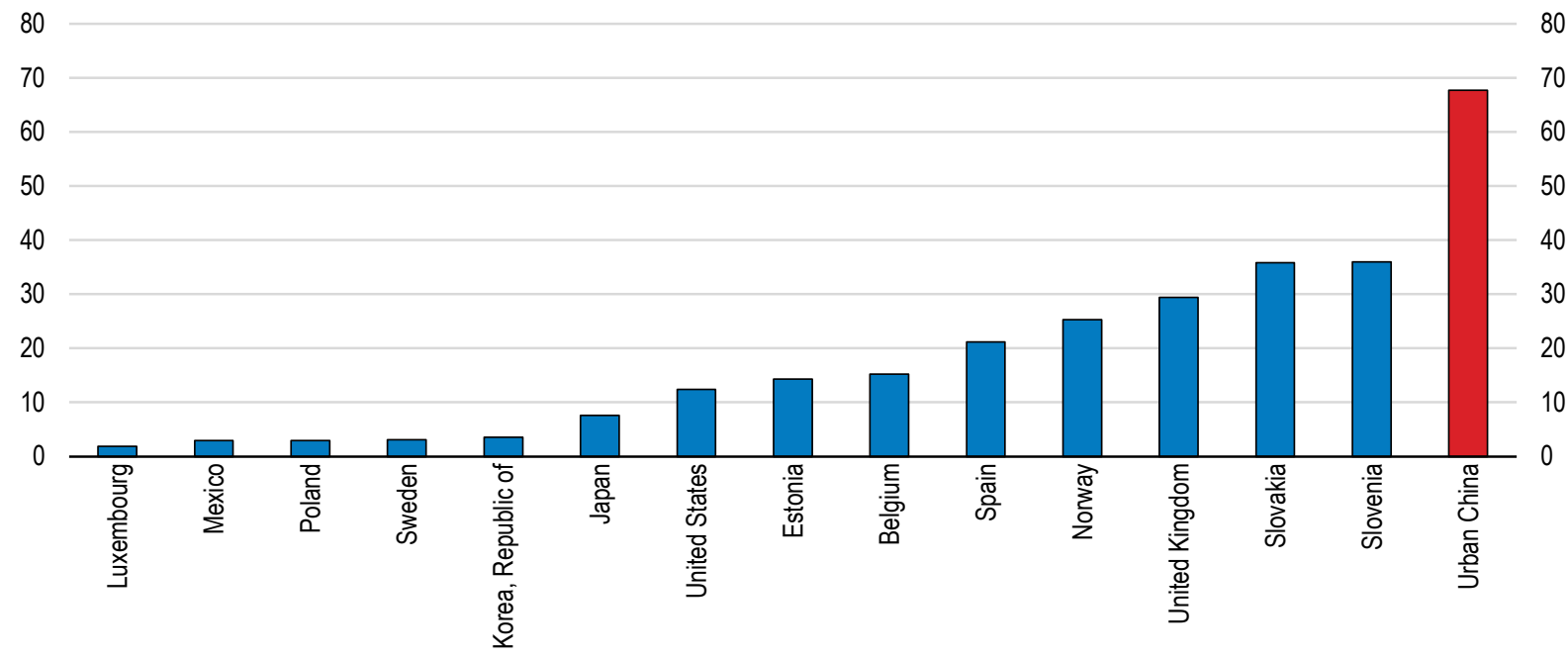

Source: OECD Taxing Wages, China Statistical Yearbook 2016, authors' calculations.

In the context of reforms to the PIT system, tax exemptions that favour high-income individuals should be abolished. For example, interest receipts from government bonds or from savings in a deposit account with a Chinese bank are currently excluded from taxable income. There are also tax exemptions on income from the sale of most shares of Chinese listed businesses (only income from the sale of "restricted shares" is taxed). 
Partly reflecting low income tax revenues, indirect taxes are relied upon to a greater extent than in most OECD countries (Lam and Wingender, 2015). China has a domestic consumption tax on specific luxury goods, alcohol and cigarettes as well as a value-added tax that has recently been expanded to services. Together, these two types of tax contributed over one third of total tax revenue in 2015. While such indirect taxes are not necessarily regressive, especially given China's exemptions for some items predominantly consumed by low-income earners, they are less redistributive than a well-functioning progressive PIT system.

The authorities could consider transferring some of the tax burden to an inheritance tax as they reform the PIT system. Inheritance taxes tend to be less distortionary than personal and corporate income taxes and can reduce inter-generational inequality (Brys et al., 2016). Furthermore, an inheritance tax could help reduce the aforementioned very high level of wealth inequality. The introduction of such a tax could be accompanied by some reasonable basic inheritance allowance to ensure it only impacts beneficiaries at the top end of the wealth distribution. Nevertheless, the proportion of total revenue raised through inheritance and gift taxes in OECD countries is relatively low. Moreover, if implemented, complementary systems are needed that can adequately value the underlying assets and monitor wealth transfers that are designed to circumvent the levy.

There are currently a range of property taxes in China, though most of these are levied on transactions. The government has long been working towards the introduction of a nationwide recurrent tax on residential immovable property. This would provide less of a disincentive for the reallocation of property and may provide a more stable source of tax revenue for sub-national governments. However, given China's very high rates of home ownership, policymakers should consider potential adverse consequences for households at the lower end of the income distribution.

Since 2011, a recurrent property tax for new home purchases has been trialled in Chongqing and Shanghai, while similar measures have been introduced in other areas (e.g. Shenzhen). While the policy design differs under the Chongqing and Shanghai pilot programmes, both have features that may benefit inclusiveness such as exemptions for smaller dwellings and higher tax rates for those with a greater market value. Even so, the majority of households are exempt from paying the tax. In Shanghai, for example, an individual who has lived in the city for more than three years and does not own a second dwelling is exempt. Any introduction of a national recurrent property tax should maximise the tax base by taxing existing dwellings and limiting the scale of exemptions. At the same time, some progressive features of the pilot schemes should be retained in the move to a national tax, such as higher tax rates for second and high value homes. A challenge for introducing a nationwide measure is that the government is still in the process of developing a countrywide property registration system that includes both new and existing dwellings. Nationwide property valuation guidelines may also be needed to ensure the measure is applied consistently across areas.

\section{The social assistance system has increased coverage but may distort work incentives}

The coverage and targeting of the social assistance system has improved in recent years, contributing to the steady decline in the number of people in poverty. China does not have conditional cash transfer schemes such as those in place under Mexico's Prospera and Brazil's Bolsa Familia programme. The main social assistance scheme is the minimum living standard guarantee programme (or dibao), variants of which exist in both urban and rural areas. The dibao is a non-contributory cash transfer to help those in poverty purchase necessities such as food, clothing and shelter. Under the scheme, a direct payment is provided to households equal to the difference between average income per person in the household and a minimum income threshold. While the programme is designed at central government level, it is 
implemented by local officials. The minimum income threshold, the precise method for calculating household income and the selection of recipients are all determined locally.

The coverage of both the urban and rural dibao schemes has expanded considerably since 2000 . The number of urban recipients rose from 11.7 million people in 2001 to peak at 23.5 million people in 2009 (Figure 6). Recipients under the rural scheme increased from 3 million in 2001 to peak at 53.9 million in 2013. Absolute coverage has declined over the past few years even though growth of the average minimum income threshold has been above that of average income at the lower end of the income distribution. Between December 2010 and September 2016, the average minimum income threshold across counties rose by above $90 \%$ and $150 \%$ in urban and rural areas respectively.

One reason for the decline in coverage in urban areas may be household members starting to claim a pension. While pension income in rural China is not included in the calculation of household income for determining the dibao, it is in urban areas. Nevertheless, the increase in the number of new urban pension recipients has not been sufficient to fully explain the decline in dibao coverage. It may be that improvements in the targeting of dibao payments have also played a part. Past analysis using rural household survey data from 2009 suggests that there were significant targeting errors: close to $90 \%$ of dibao recipients had ex ante income above the county minimum income threshold (Golan et al., 2015). There is also evidence that the targeting error for the urban dibao was high and rising between 2002 and 2007 (Gao et al., 2015). More recent analysis using survey data from five administrative regions suggests some improvement in dibao targeting in rural areas between 2012 and 2014 (Westmore, 2017). Along with the introduction of fines for local government officials or dibao recipients found to be acting improperly, databases have been gradually developed to help verify payment eligibility. Various ministries have collaborated on a database that provides information about household income sources and asset holdings, accessed conditional on prior authorisation by the household. This tool is only operational in a few of the most developed cities such as Shanghai and Guangzhou, but there are plans to roll it out nationwide.

Figure.6. The coverage of the dibao programme has peaked in both urban and rural areas

Number of dibao recipients, million people

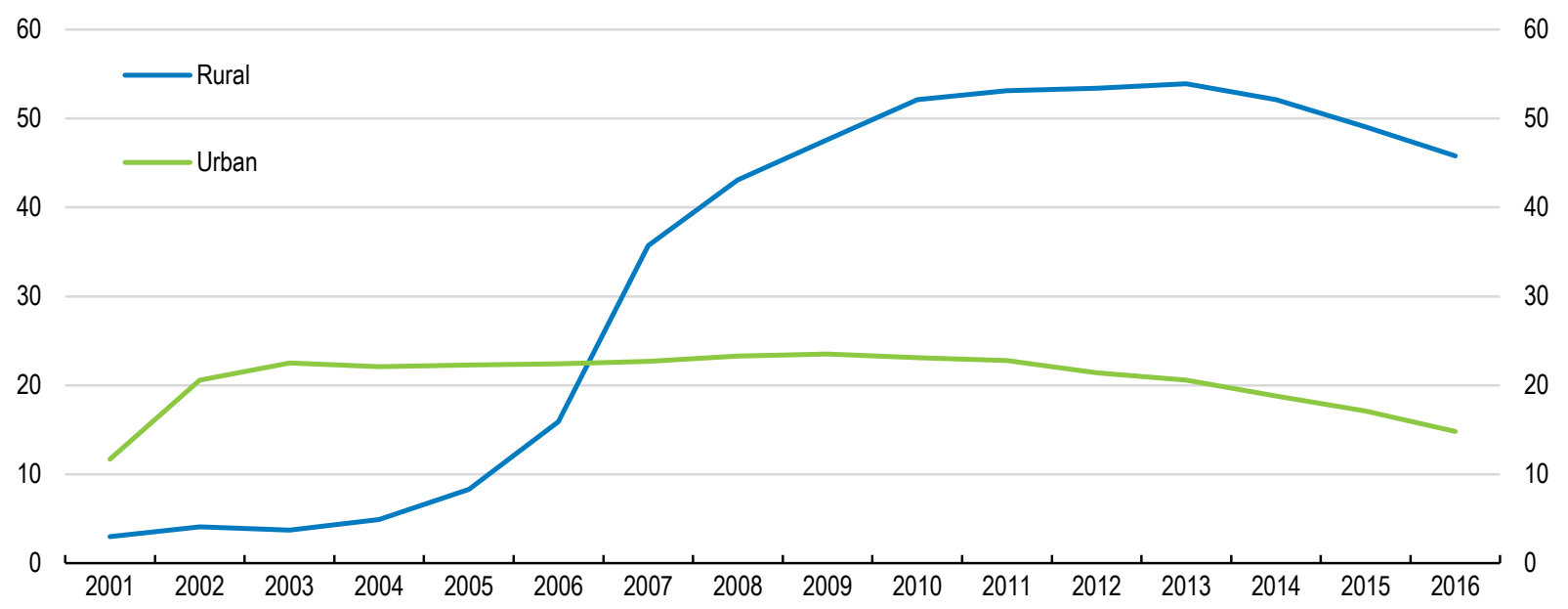

Source: China Civil Affairs Statistical Yearbook.

Part of any remaining targeting errors may be due to the decentralised nature of the scheme and variations in practices for assessing dibao eligibility. Household assets are meant to be taken into account for deciding if an applicant can claim dibao. However, there is no national procedure specifying the types of assets that should be considered. Similarly the method for calculating the income of family members 
living outside the local area is not uniform. While some counties may use actual income, others use the average or statutory minimum wage in the location where the family member is working. The government has made various attempts to clarify the planned regulation of the dibao system, including a circular on "Interim Measures for Social Assistance" in 2014 (MCA, 2014). However, more needs to be done to monitor the effectiveness of local systems. An increased number of inspections by representatives of the central government and greater efforts to ensure that citizens are able to easily report corruption or unfair practices in the administration of dibao are paramount.

Figure 7. The minimum income threshold varies significantly across provinces

Average provincial minimum income threshold under the dibao programme, CNY per month (September 2016)

A. Urban

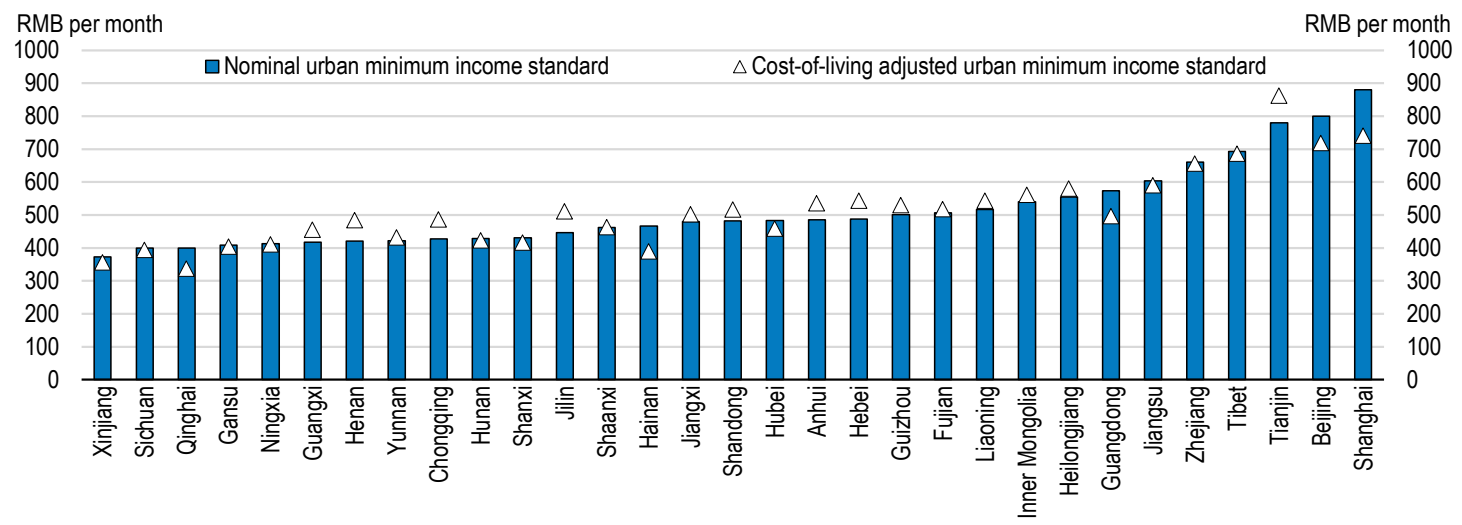

B. Rural

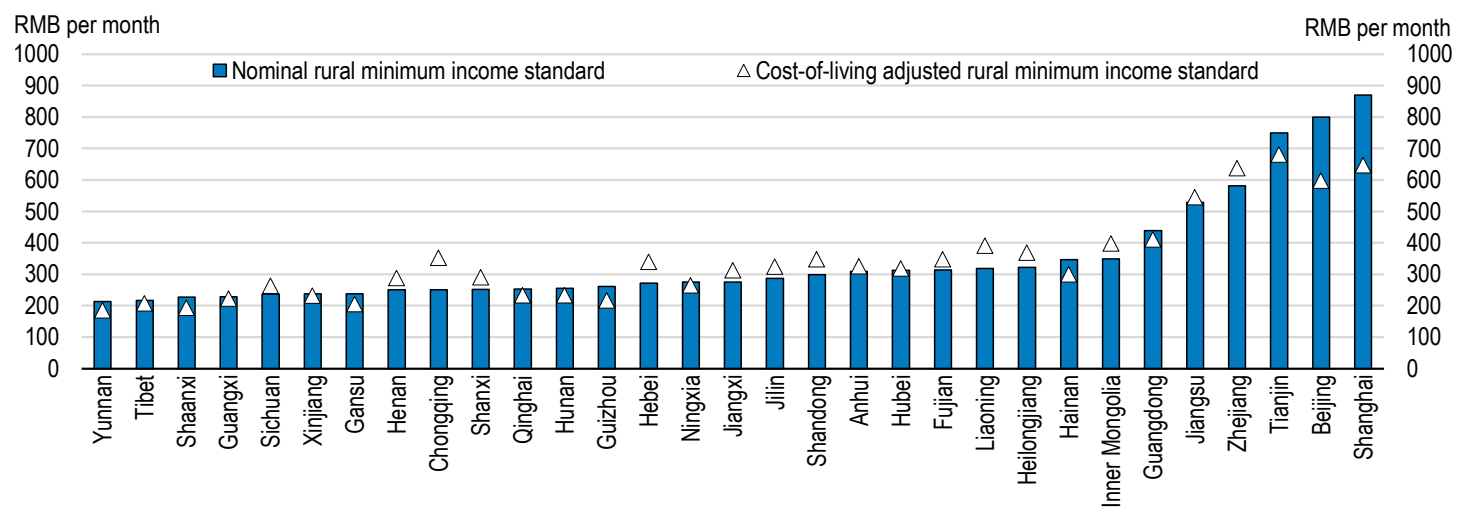

Note: Separate spatial price deflators for rural and urban areas in each province are taken from Brandt and Holz (2006) and then extrapolated using the province-specific consumer price index. Li and Gibson (2013) outline potential limitations with such a methodology.

Source: China Ministry of Civil Affairs, CEIC, Brandt and Holz (2006), authors' calculations.

The local administration of the dibao has led to significant differences in the minimum income threshold both between and within provinces. In September 2016, the average urban minimum income threshold in Shanghai was double that of 11 other provinces (Figure 7). At the same time, within Guangdong Province, for example, the threshold in parts of urban Guangzhou was over double that in urban Leizhou, a county-level city located in southern Guangdong (Box 2.1). Part of such differences can be attributed to cost of living variations between locations. However, this only partially accounts for the discrepancies. When controlling for absolute price levels between provinces, there are still substantial differences between the minimum income thresholds (Figure 8). These residual differences largely reflect the financing capacity of local governments, with poorer areas tending to have lower minimum thresholds and, thus, dibao transfers than richer areas (Leung and Xiao, 2015; Golan et al., 2015). While both the 
central and provincial governments channel fiscal transfers to locations in greatest need, this does not seem to be sufficient. As such, existing inequalities between regions may be reinforced through the current system. Central and provincial governments should increase transfers to the poorest areas to enable a costof-living adjusted subsistence payment that is more in line with that in richer locations.

\section{Box 1. Variation in China's Minimum Income Threshold}

The income threshold under China's dibao programme is set at the prefecture level. Then, local authorities in each county within the prefecture can choose to fund an increase in the threshold in their location. In 2012, the central government released the Opinion on Furthering the Regulation on the Formulation and Adjustment of Dibao Standards to communicate to local governments the principles that should be followed when setting the minimum income thresholds. Nevertheless, there is no universal model for their calculation. The local minimum wage, average local per capita income or the national rural poverty line may all be used as reference points depending on the location. Some local authorities also link the threshold to the proportion of the household budget of low-income people devoted to basic food and to the cost of local basic necessities (Guan, 2016).

\section{Figure 8. Minimum income thresholds vary greatly within provinces}
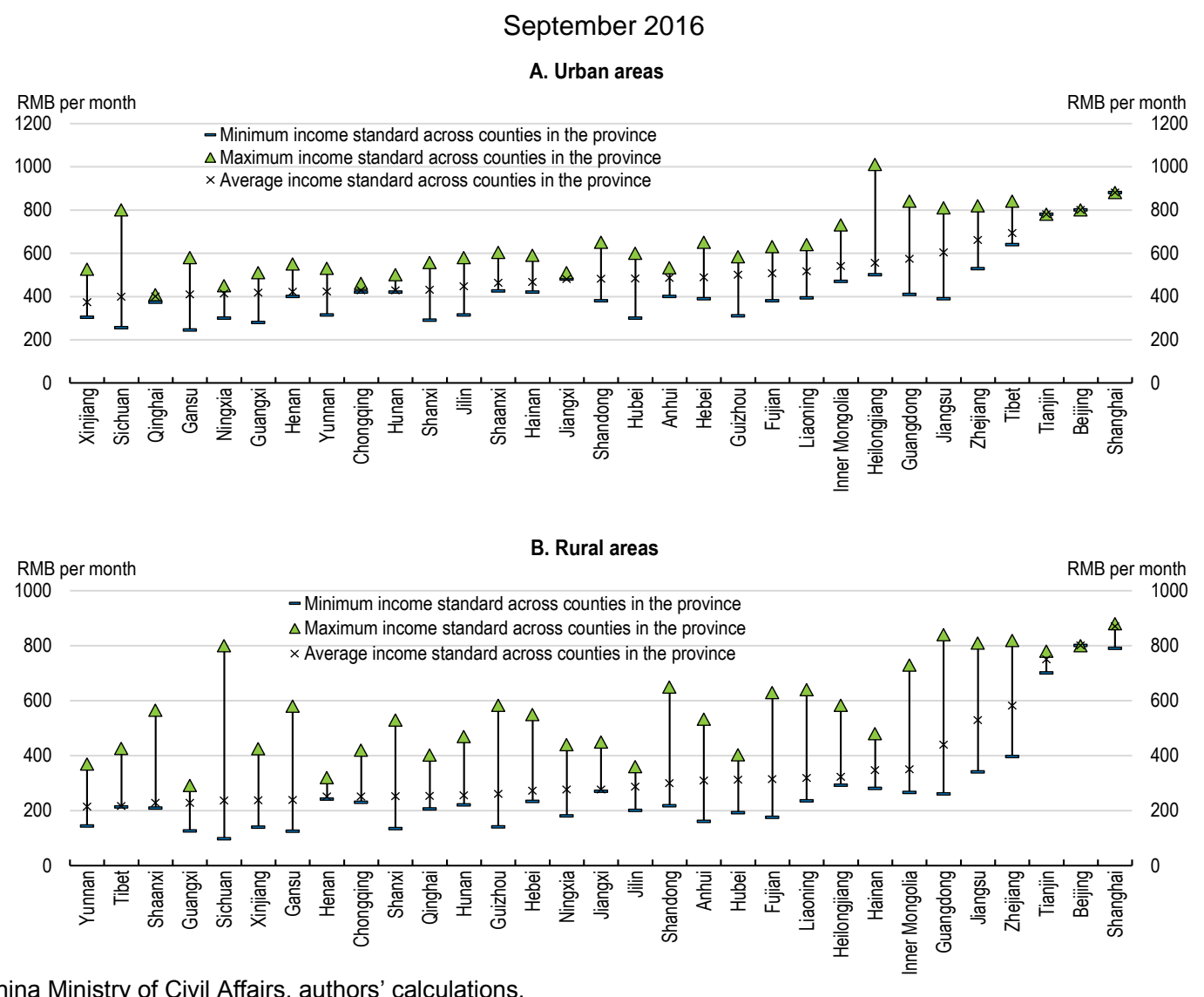

Source: China Ministry of Civil Affairs, authors' calculations.

Differences in local government financing capacity and the diversity of methods used to calculate the minimum income threshold has contributed to substantial variation within counties in the same province. While the municipalities of Beijing, Tianjin and Shanghai have implemented a uniform threshold across counties in urban areas, the difference between the maximum and minimum county threshold in the other provinces is, on average, $50 \%$ of the average minimum income threshold of the province (Figure 8, Panel A). The within-province variation is even more pronounced in rural areas, averaging above $100 \%$ of the average provincial minimum income threshold (Figure 8, Panel B).

Internal migrants cannot apply for dibao in the location where they reside, but only in the county where their household registration (hukou) is located. This policy and the differences in the minimum 
income thresholds mean that an eligible migrant from a rural area in Yunnan Province living in Beijing will, for instance, receive a much lower dibao transfer than one from rural Jiangsu. This creates horizontal equity issues and means that the relative living conditions and opportunities of some migrants are impaired due only to the province or county they happen to come from. While providing dibao for migrants according to their destination city is problematic, as it may encourage welfare migration, increasing the dibao payments in poorer areas through increased central and provincial government transfers would reduce the inequities between migrants from different locations.

The design of the dibao system may inadvertently slow the income growth of the poor by providing a disincentive for them to take up work: an increase in household wage income will result in a proportionate decrease in the dibao benefit received. This implies an effective tax rate on participation of $100 \%$ on any amount of wages up to the minimum income threshold. In contrast, the effective tax rates on participation of low-income earners entitled to social assistance in the United States and France were reported to be $28 \%$ and $64 \%$ respectively in 2014 .

In an increasing number of OECD countries, provisions are made in the social assistance system to ensure the lowest income workers are not dissuaded from entering the labour market. Such policies have a positive impact on labour force participation (Immervoll and Pearson, 2009). One method is through the introduction of "in-work benefits", whereby those who take a low-paid job continue to receive some government income support in addition to their wage. Introducing such measures in China is advisable, especially in those locations with a relatively high minimum income threshold which are likely to have the largest aggregate negative participation effects.

Some locations already have measures to reduce the participation tax rate inherent to the dibao scheme. For example, a portion of any increase in household salary may not be included as assessable family income for calculating the dibao benefit for a defined period (usually three to six months). In addition, empirical studies hint that the practices of some local officials reduce the participation tax rate. In a study of seven Chinese cities, Ravallion and Chen (2015) estimate the actual effective tax rate at 7\%, implying low levels of benefit withdrawal as incomes rise. They contend that this is because local officials in those areas do not reduce the dibao transfer payments as stipulated by the central scheme design.

In addition to dibao, a high proportion of low-income households receive agricultural subsidies from the government (Westmore, 2017). These payments have the purpose of providing income support, primarily to rural households, but also promote other government objectives such as agricultural modernisation and grain self-sufficiency (OECD, 2015a). There are also more targeted social assistance measures for a smaller number of extremely poor people. These include cash and in-kind benefits for the elderly, disabled and minors under the aged of 16 who have no dependents, no ability to work and no source of income. Such benefits (the tekun programme) are focused on five basic provisions (clothes, food, medical care, housing and burial expenses), with eligibility partly determined by local governments. In 2016, around 5 million people in rural areas received such assistance.

China also has special and temporary social assistance programmes such as medical financial assistance, education assistance and heating subsidies which provide support for poor and low-income families, often jointly funded by the central and local governments. Eligibility for these additional assistance measures is typically linked to dibao eligibility. Receiving the dibao as well as these other benefits may raise the material wellbeing of some impoverished households above that of other households whose per capita market income exceeds the minimum income threshold (World Bank and DRC, 2014). This may create a disincentive for the former group to move from inactivity to work. In future, some decoupling of eligibility for these additional assistance measures from dibao should be considered. Local governments should also be further encouraged to assess potential perverse effects on work incentives when selecting the beneficiaries of additional social assistance support. 


\section{Unemployment insurance coverage is low}

Unemployment benefits can reduce the risk of individuals slipping into poverty and improve jobsearch capacity. China's unemployment insurance system is partly funded by worker and employer contributions. Benefits are paid by the local government at a flat rate, conditional on the worker having paid into the scheme for more than one year and registering their unemployment status after being involuntarily terminated. While the coverage rate has increased in recent years, it remains low (OECD, 2015 b). In 2015 , just $43 \%$ of the urban employed contributed to unemployment insurance.

The expansion in the dibao scheme in recent years may have encouraged some unemployed workers to claim social assistance instead of unemployment insurance. While the dibao benefit is always lower than the unemployment benefit, no employee contributions are required to be eligible. At the same time, the incentive structure of local government officials may not sufficiently reward successful targeting of social welfare payments (Qian and Mok, 2016).

The replacement rate for the unemployed is low by OECD standards. This may rush unemployed workers from low-income families to take a job regardless of the compatibility with their skills, reducing the efficiency of labour market matching and the chance to forge a successful career. In 2014, the average unemployment insurance benefit in China was around $18 \%$ of the average urban wage. This contrasts with an average net replacement rate above $60 \%$ in the OECD for an individual who previously earned $67 \%$ of the average wage. While the average unemployment benefit level in China rose by around $13 \%$ per year during the 2006-14 period, this increase did not fully keep pace with nominal urban wage growth. Furthermore, the fact that benefits are not linked to past earnings may not encourage workers to take a formal sector job compared with a system where such a link exists.

\section{Better targeted poverty-reduction benefits remain necessary}

With tens of millions of people still in poverty, despite the expansion of the dibao programme, further improvements to the social security system and better targeting of poverty-alleviation programmes remain necessary. The importance of targeting is highlighted by the differences in poverty rates across provinces. While the published rural poverty rate in Zhejiang was around $1 \%$ in 2014 , over $20 \%$ of the rural population in Gansu were in poverty at the time. Such disparities are confirmed by household level estimates computed from China Family Panel Studies data (see Box 2 for details). Recognising such differences, since 2013, public funding for poverty relief has been targeted at 832 counties that are mostly located in 14 contiguous "extremely poor" regions.

Poverty reduction funding is currently spread across a diverse set of rural development projects. In accordance with the government's China Rural Poverty Alleviation and Development Programme (201120 ), project areas include water conservation, electricity supply, roads and public transport connections, education, medical hygiene and culture (CPGPRC, 2011). Ongoing reforms that better allow rural residents to transfer land rights, such as those currently being piloted in Anhui province, will be important (such reforms were discussed extensively in the OECD China Economic Survey 2015). Furthermore, initiatives relating to e-commerce that allow better targeting and tailoring of policies can also benefit poverty reduction. A database has been established by the government for this purpose which has personal information about citizens deemed to be living below the poverty line.

The central government also provides financial support for the relocation of impoverished people to areas with better job prospects. By 2020, the government aims for an additional 10 million people to move either to parts of the same prefecture that have better developed public services or to thriving commercial areas that are further away. Under the programme, the relocated rural citizens retain use rights to their rural 
land and are given generous subsidies that cover the majority of their housing costs and other expenses. They are also provided with employment services to help them integrate into the local labour market. For each person, the central government transfers around CNY 60000 to the local government (that manages the subsidies). Residents move on a voluntary basis, with the sum of the government subsidies thought to provide a substantial incentive. Nevertheless, past case studies have documented that voluntary resettlement programmes in China are often related to the withdrawal of government services at the migrant's original location, which gives the resident little choice but to move (Wilmsen and Wang, 2015). This highlights the need for comprehensive assistance for the relocated population to ensure that nonincome elements of their wellbeing are not being neglected as a result of the programme.

Poverty may be reduced through government plans to provide household registration permits to some currently unregistered citizens. Around 13 million people have restricted access to public services and social security benefits because they do not hold a hukou. In January 2016, the State Council issued an opinion outlining eight types of unregistered citizens who should be given a household registration permit (State Council, 2016a). These included people born out of wedlock or with a foreign or stateless parent, people born in contravention of China's family planning policies, people not in possession of a birth certificate or complete adoption papers and those who have moved location but do not possess relevant transfer documents. Following the opinion, provincial governments were urged to develop specific plans to register these citizens. Although most provinces had released such outlines by mid-2016, a number of provinces with a relatively high share of unregistered citizens have still not articulated their policy.

\section{Social housing}

Access to decent-quality housing can be an important enabling factor for participation in the community and is associated with other aspects of wellbeing such as health, education and employment. However, housing costs can sometimes be prohibitively high for households at the lower end of the income distribution. In OECD countries, the incidence of housing cost overburden has been found to be especially high among low-income households (Salvi del Pero et al., 2016). The analysis in Box 2 suggests this has also been the case in some parts of China. In 2014, both the average urban and rural household living below the poverty line in Shanghai, Henan and Gansu had a higher share of their expenditure consumed by housing costs than the average household not living in poverty.

Over the past decade, the Chinese government has displayed a strong commitment to the provision of public housing for low-income households, with a large-scale public housing construction programme implemented since 2009. Public housing support in China takes many forms, with the government either providing financial assistance for housing costs or directly providing accommodation.

One method of housing support is when sub-national governments allocate free land to property developers to build housing for low-income households. Under this model, it is agreed that the profit margin of the developer will not exceed a certain threshold - usually around 3\% (Huang, 2015). Qualified households can then purchase partial property rights to the housing at government-controlled prices. One problem with this approach is that sub-national governments rely heavily on the revenues derived from land sales to undertake new public investment and service debts (OECD, 2015a). Consequently, undesirable plots of land that are remotely located with poor access to public services and work opportunities are often those allocated for social housing development.

The government may also give financial subsidies to low-income households who rent housing from the private market or may directly provide rental housing at government-controlled rents. The vast majority of the public financial support is provided by subnational governments. However, partly due to this funding structure, migrants who do not have a local hukou tend to face difficulty accessing such support (Huang, 2015). While the government has introduced new programmes explicitly open to migrants without 
a local hukou, these have primarily been used to attract talented professional rather than those with lower incomes (World Bank and DRC, 2014).

Furthermore, local governments have increasingly been introducing inclusionary housing requirements for new private developments. Under this system, urban land is made available to property developers under the condition that a proportion of the new development must be set aside for low-income housing. In part, this is a response to ambitious social housing targets of the central government that are cascading to the subnational level. While the stock of such housing is still relatively low in China, the model of inclusionary housing can be beneficial for fostering social networks and reducing the chance that low-income housing is isolated on urban fringes. However, in many cases, the allotment for low-income housing is isolated within the development, sometimes by the erection of physical barriers from the other housing units or through the presence of separate entrances (Huang, 2015). These characteristics limit the potential social benefits of such a model.

\section{Box 2. The impoverished households in five Chinese administrative regions}

Using 2014 household survey data from the China Family Panel Study (CFPS), the characteristics of households who lived below a defined poverty line can be examined. The CFPS is a large-scale panel survey conducted by the Institute of Social Science Survey at Peking University. The survey covers Shanghai, Liaoning, Henan, Gansu and Guangdong. The sampling strategy ensures representativeness at the province-level, allowing for province-level inferences and cross-province comparisons for these regions. The analysis below is based on the survey responses of 5543 households (for further details, see Westmore, 2017).

A poverty rate can be estimated by combining reported family income per capita and a defined poverty line. The national rural poverty line of CNY 2300 at 2010 prices is used for rural households (extrapolated to 2014 using the national consumer price index), while the urban poverty line is defined as the average urban minimum income threshold across 31 provinces in 2014 that is then adjusted for cost-of living differences between the five administrative regions that are the focus of this analysis.

The estimates highlight significant differences in poverty conditions between locations in 2014. Across all households living in these five provinces, the estimated overall poverty rate was highest in Gansu (25.2\%) and lowest in Shanghai $(2.6 \%)$. In each province outside of Shanghai, the estimated rural poverty rate was significantly higher than the $7.2 \%$ national rural poverty rate for 2014 reported by China's National Bureau of Statistics.

Table 1. Poverty rates vary greatly across areas

$\%$ of sampled population, 2014

\begin{tabular}{|c|c|c|c|c|c|c|c|c|c|c|}
\hline & \multicolumn{2}{|c|}{ Shanghai } & \multicolumn{2}{|c|}{ Liaoning } & \multicolumn{2}{|c|}{ Henan } & \multicolumn{2}{|c|}{ Gansu } & \multicolumn{2}{|c|}{ Guangdong } \\
\hline & Urban & Rural & Urban & Rural & Urban & Rural & Urban & Rural & Urban & Rural \\
\hline Poverty rate & 2.9 & 0.8 & 11.1 & 13.4 & 21.8 & 19.1 & 28.5 & 24.4 & 18.8 & 17.3 \\
\hline
\end{tabular}

Source: CFPS, authors' calculations.

The CFPS survey also collects information about the expenditure baskets of households. This allows some descriptive analysis of the difference in the composition of household expenditure depending on poverty status. Across the five provinces, households below the poverty line spent a notably higher share of their income on medical care and housing, on average, than those not in poverty.

Focusing on medical expenses, the difference in expenditure share between the two groups was especially pronounced in urban Shanghai and Henan and rural Liaoning (Table 2). For Shanghai, this may partly reflect the large number of migrant workers, many of whom were likely covered by rural health insurance schemes that had lower reimbursement rates in 2014 (Yu, 2015). 
Figure 9. Impoverished households spent more of their income on health and housing Share of total expenditure (\%), 2014

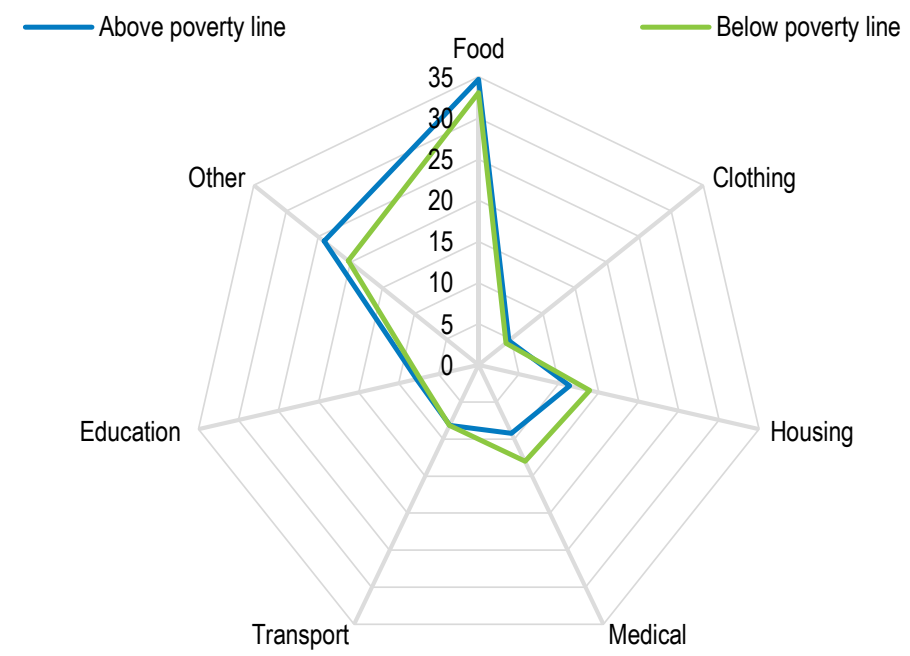

Source: CFPS, authors' calculations.

The housing expenditure share was relatively high for those in poverty in both urban and rural areas in each of the provinces, with the exception of rural Guangdong and rural Liaoning. From 2000, housing affordability among the poor became a significant issue in many areas. This was partly due to a decline in the share of "economic housing" in total housing investment between 2000 and 2008 (Huang, 2012).

Table 2. The impoverished in most regions spent more of their income on health and housing Average \% of total household expenditure, 2014

\begin{tabular}{c|c|c|c|c|c|c|c|c|c|c}
\hline & \multicolumn{2}{|c|}{ Shanghai } & \multicolumn{2}{c|}{ Liaoning } & \multicolumn{2}{c|}{ Henan } & \multicolumn{2}{c|}{ Gansu } & \multicolumn{2}{c}{ Guangdong } \\
\hline & Urban & Rural & Urban & Rural & Urban & Rural & Urban & Rural & Urban & Rural \\
\hline Medical share & & & & & & & & & & \\
\hline Above poverty line & 6.9 & 8.1 & 7.8 & 9.5 & 9.1 & 11.6 & 9.6 & 12.2 & 5.6 & 10.1 \\
\hline Below poverty line & 11.9 & 6.8 & 10.7 & 14.8 & 14.9 & 15.8 & 9.1 & 13.7 & 9.1 & 11.5 \\
\hline Housing share & & & & & & & & & & \\
\hline Above poverty line & 10.0 & 12.1 & 10.9 & 10.8 & 10.4 & 9.4 & 12.1 & 15.4 & 11.5 & 10.3 \\
\hline Below poverty line & 13.1 & 13.6 & 15.3 & 9.4 & 10.5 & 11.4 & 16.3 & 18.7 & 13.5 & 8.6 \\
\hline
\end{tabular}

Source: CFPS, authors' calculations.

\section{Helping low-paid workers improve their productivity and appropriate the rewards}

Inclusive growth can also be achieved by ensuring that marginalised groups have the opportunity to find jobs, improve their skills and derive the benefits from increasing their productivity. Indeed, improving market outcomes for low-paid workers should be the first priority for policymakers aiming to reduce inequality in disposable incomes. Educational opportunities at all levels are key to this process. So too are labour market institutions that help match workers to the most appropriate jobs and ensure that they receive a fair wage. Targeted policies that promote participation for those workers typically subject to discrimination, such as internal migrants and women, are also critical. The benefits of inclusive education 
and labour market policies should emerge through higher financial rewards for marginalised workers. However, such policies are also integral to promoting non-income dimensions of wellbeing (OECD, 2014).

\section{Educational opportunities are still relatively poor in rural areas}

Educational opportunities shape people's destiny in the labour market, their productivity and their well-being. In 2015, Chinese students from Beijing, Shanghai, Jiangsu and Guangdong, who were tested for the Programme for International Student Assessment, outperformed the average OECD country cohort in science and mathematics and performed similarly in reading (OECD, 2016a). However, compared with OECD countries, socioeconomic factors explain a larger part of the variation in China's PISA results (Figure 10). This reflects broader inequalities in educational opportunities, stemming primarily from the urban-rural divide (Yang et al., 2014). Such inequalities are reinforced by China's fiscal system. In particular, the significant spending mandates of subnational governments are only partially funded through fiscal transfers (Gong, 2013).

The available evidence highlights particularly large disparities in enrolment rates between urban and rural children in pre-primary education (Chen et al., 2015). This is a concern because a lack of early childhood education can lead to poorer prospects for employment, income and health later in life (Campbell et al., 2014). As stressed in the OECD Economic Survey of China 2015, pre-school education should be compulsory for at least one year (OECD, 2015a). This is a key priority for making growth more inclusive and could be facilitated by greater funding from central and provincial governments. While rural enrolment rates in compulsory education have typically been almost as high as in urban areas, far fewer rural students aspire to a college education (Chen et al., 2015).

The quality of education is also significantly lower in many areas of rural China. This reflects low teacher salaries and poor professional development. While training opportunities are currently available for teachers in many schools in poor rural areas, the low supply of staff and high number of students make it difficult for them to take time away from their classes (Peng et al., 2014). Furthermore, overcrowding in classrooms is a problem. Recognising this, the State Council issued a notification in mid-2016 stating a commitment to reducing all class sizes in rural schools below 56 students by 2020 (State Council of China, 2016b). However, even a class size of 56 would be much higher than the average of any OECD or emerging country (OECD, 2016a). The notification also indicated a willingness to fund higher rural teacher salaries in poor areas. While such initiatives should be beneficial, there is also a need to continue developing more sophisticated methods of school and teacher evaluation.

Migrant children following their parents to cities have been increasingly given access to city schools. Nevertheless, enrolment rates have been typically lower than their counterparts with an urban hukou, partly reflecting prohibitive enrolment conditions set by the provincial and municipal governments (OECD, 2015a). Reforms announced in 2016 that tie central government education funding to children's place of residence, rather than place of registration, may encourage local governments to welcome more migrant students into the school system. However, this would require increased funding by the central government, as education costs per student tend to be much higher in the cities with a large migrant population than in rural areas. 
Figure 10. Socioeconomic factors have a large influence on Chinese PISA scores Impact on PISA score of a one unit increase in the PISA index of economic, social and cultural status, 2015

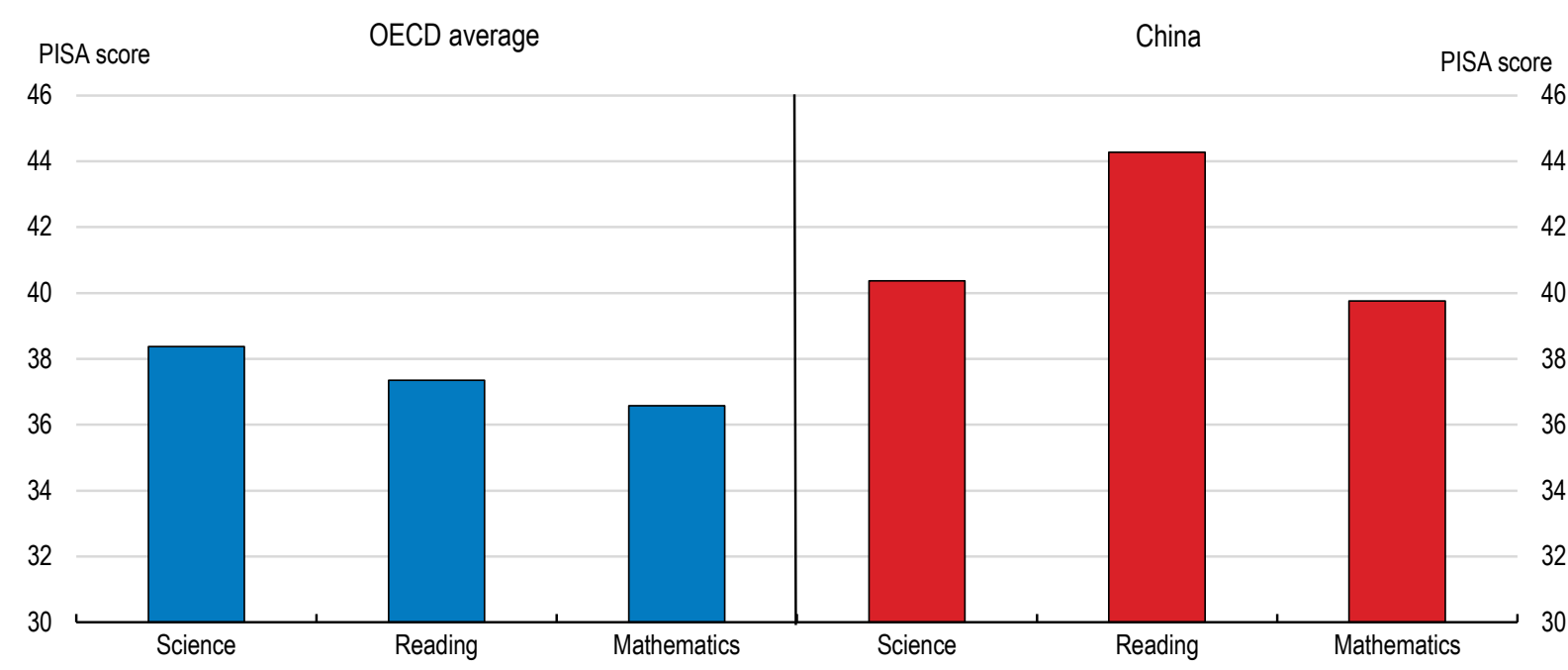

Note: The PISA index of economic, social and cultural status is a composite indicator derived using principal component analysis from several variables related to the family background of students. Parent education, parent occupations, various home possessions that proxy material wealth and the number of books and other educational resources available in the home are inputs to the index.

Source: OECD.

The low quality of education received by migrant children may reduce their opportunities later in life. The majority of such children are enrolled in low-quality public schools or in unlicensed migrant schools (Fang et al., 2016). Particularly in cities where educational resources are scarce, there are large gaps in the quality of education provided to migrant children compared with those who hold a local hukou (Xu and $\mathrm{Wu}, 2016)$.

Along with providing all citizens the opportunity for a good quality general education, there needs to be more emphasis on retraining low-paid workers during their working lives. The ongoing rebalancing of industry to more "new economy" tasks makes this a priority. China's National Plan for Medium and Longterm Education Reform and Development 2010-20 aims to double the number of participants in lifelong learning programmes to 350 million by 2020 (Ministry of Education, 2010). Workplace-based vocational training is one channel for such programmes. However, the system is still underdeveloped, with better coordination between employers, teachers, students and the government needed. Furthermore, while employers are required to allocate $1.5-2.5 \%$ of the wage bill for continuous training purposes, the amount that is allocated in some cities is considerably less (OECD, 2015a). Online education has been growing rapidly and holds great potential as a platform for lifelong learning. In 2015, there were 110 million online education users, equivalent to $16 \%$ of all internet users in China (China Internet Network Center, 2016). Nevertheless, the quality of online courses varies greatly and the authorities should improve the monitoring, evaluation and quality assurance of such programmes.

\section{Labour market institutions have been established to promote job quality and fair wages}

\section{Job-matching and training}

Policies that facilitate efficient resource allocation are important for labour market matching (Adalet McGowan and Andrews, 2015). For example, encouraging greater competition in network sectors and accelerating the bankruptcy process in China (as discussed in Molnar, 2017) should reduce skill mismatch, 
thus improving worker productivity. Furthermore, institutions tasked with matching workers to appropriate jobs and implementing active labour market policies are important to this end.

The number of public employment service offices has surged in China since the early 2000s. There are currently around 11000 such offices at the regional level and 40000 in local areas that are co-funded by central and local governments (OECD/IDB/WAPES, 2016). Compared to many other countries, the job placement services are comprehensive. Job seekers register and administer their profiles online and a database is used to match job seekers to vacancies. The centres also organise training opportunities for job seekers and job fairs for interacting with prospective employers. The increase in government funding for such services over the past decade is likely to have contributed to narrowing inequalities in income (Solt, 2016) as well as broader measures of wellbeing.

There are various active labour market programmes through public employment services, including vocational guidance, temporary work trial programmes and self-employment schemes. These programmes are particularly targeted at marginalised job seekers, such as migrant workers, disabled persons, women, ethnic minorities and the elderly (OECD/IDB/WAPES, 2016). Nevertheless, the share of the operational budget of China's public employment services devoted to active labour market policies is below that of countries with well-established programmes such as Germany and Denmark.

Some measures are linked to the social security system. For example, able-bodied recipients have their dibao benefits reduced or rescinded if they reject job referrals from employment service centres three times. Nevertheless, the fact that public employment services have no role in administering dibao payments often leads to coordination difficulties in enforcing this policy.

\section{Ensuring workers are paid a fair wage}

Trade unions in China play a relatively minor role in negotiating a fair salary for workers. The AllChina Federation of Trade Unions, China's sole legally mandated trade union, has 288 million members and communicates with 5-6 million enterprises. However, union representatives do not negotiate wages on behalf of employees. Instead, their role is mostly to advocate adherence to labour laws and to identify areas in which they can provide support services (including financial assistance) to workers. They also ratify changes to minimum wages, after they are determined by provincial governments and approved by the Ministry of Human Resources and Social Security.

China has had a statutory minimum wage since the early 1990s in order to ensure work pays for lowincome employees. Empirical evidence focusing on urban areas suggests that increases in the minimum wage have had beneficial effects on income distribution through reducing the gap between the median and bottom decile (Lin and Yun, 2015). There is no national minimum wage, but a series of local minimum wages set by provincial governments. Within the same province, the minimum wage level can vary materially. For example, in Guangdong Province, the most recently mandated minimum wage for Tier 1 cities was close to $60 \%$ higher than that for Tier 4 cities. Guidance from the central government recommends that the mandated level should consider the local cost of living and any negative consequences for employment of setting the minimum wage too high.

There is significant dispersion in the minimum wage level across provincial capitals, even when controlling for the local average wage (Figure 11). This highlights the discretion of provincial governments in setting the minimum wage level. On average across provincial capital cities, the minimum wage was $27 \%$ of average wages in 2014. This was notably lower than in OECD countries, where the average ratio of the minimum wage to average earnings of full-time workers was close to $40 \%$ in 2014. However, in some parts of China, there are concerns that further minimum wage increases will reduce the competitiveness of 
the business sector. In early 2016, Guangdong Province imposed a two-year minimum wage freeze. Furthermore, evidence suggests the adverse employment effects of some past minimum wage increases fell on groups already facing hurdles to labour market participation such as the low-skilled and females (Fang and Lin, 2013). As such, while there appears to be scope for an increase in the average minimum wage, the potential for negative employment effects in some locations should continue to be carefully considered. While the authorities could provide an in-work wage subsidy to minimum wage earners, supporting those at the bottom of the income distribution without inflating business costs, this may lead to an increase in undeclared (i.e. "envelope") wages if not coupled with stricter enforcement of regulation to prevent informal employment.

Figure 11. Minimum wages are low compared with OECD countries

Ratio of minimum wage to average wage by province, 2015

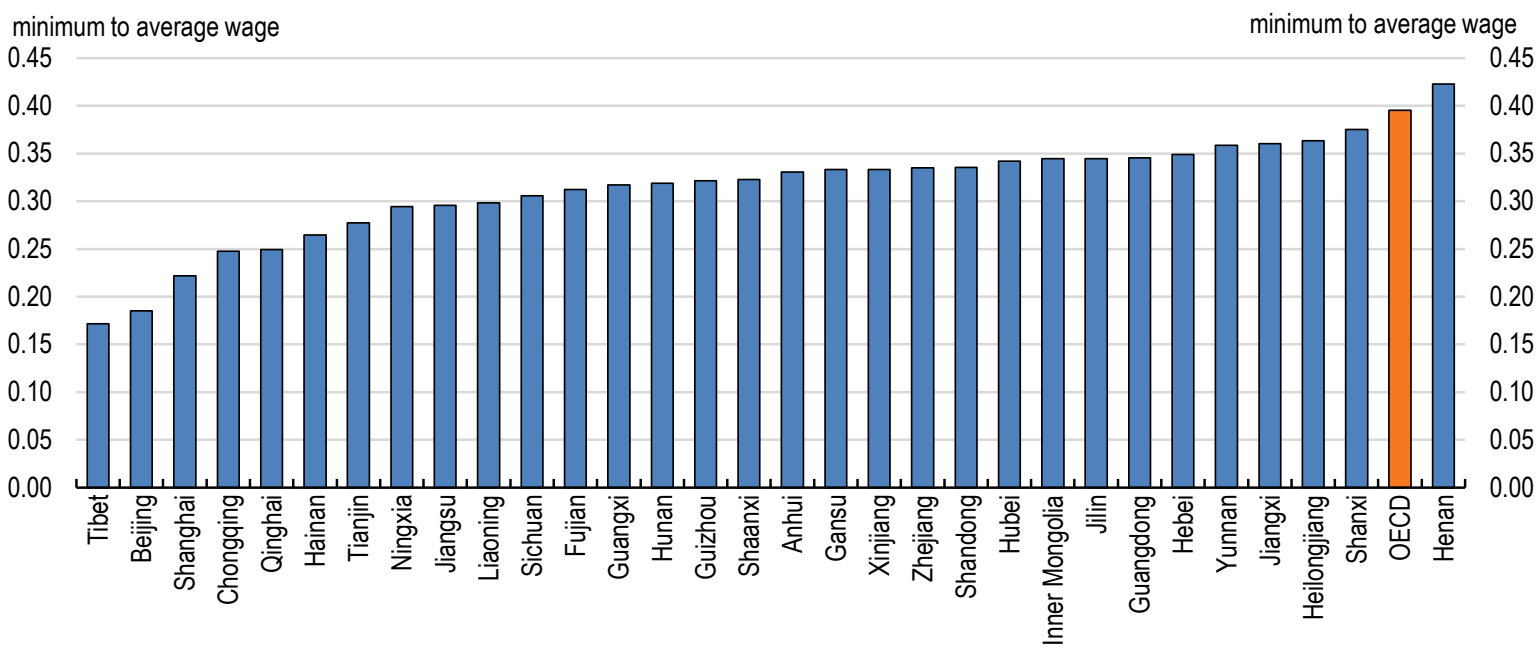

Note: The OECD bar is a simple average of the ratio of the minimum wage to average wage of full-time workers in 27 OECD countries in 2015.

Source: Ministry of Human Resources and Social Security, CEIC, OECD, authors' calculations.

\section{Labour market opportunities for some groups are reduced by policy distortions}

\section{Migrant workers from rural areas}

Rural-to-urban migrants are one group that still face low status, badly paid and sometimes dangerous jobs. The authorities have made progress in recent years in severing the link between hukou status and welfare entitlements: in mid-2014, a single national resident registration system (jumin hukou) for both rural and urban populations was established. Nevertheless, the criteria for gaining residency in the most popular destination cities for migrants remain prohibitively strict for most migrant workers (see Box 3 for further details). The inability of the children of many migrant workers to access education and health services in cities has led to some 60 million children of migrant workers being "left behind" in their rural place of origin, having a negative impact on their mental health (Shi et al., 2016).

In 2015, 60\% of migrant workers did not have employment contracts (Figure 12). As a result, such workers were not legally entitled to the minimum wage nor covered by China's labour laws, increasing their vulnerability to cyclical fluctuations and discriminatory practices by employers. Less than one quarter of migrant workers had contract duration greater than one year. This is consistent with OECD evidence highlighting that urban informal workers in China who transit to formality tend to move to temporary jobs (OECD, 2015b). For those workers with no contract or on a short-term arrangement, the incentive for 
either firms or workers to invest in firm-specific skills development is low. At the same time, employment protection legislation for temporary workers is particularly lax in China compared with the laws for regular workers. This may amplify the vulnerability of migrant workers, especially considering the low proportion of migrant workers who have unemployment insurance.

Figure 12. A large share of migrant workers do not have labour contracts

Contract status of migrant workers (\%), 2015

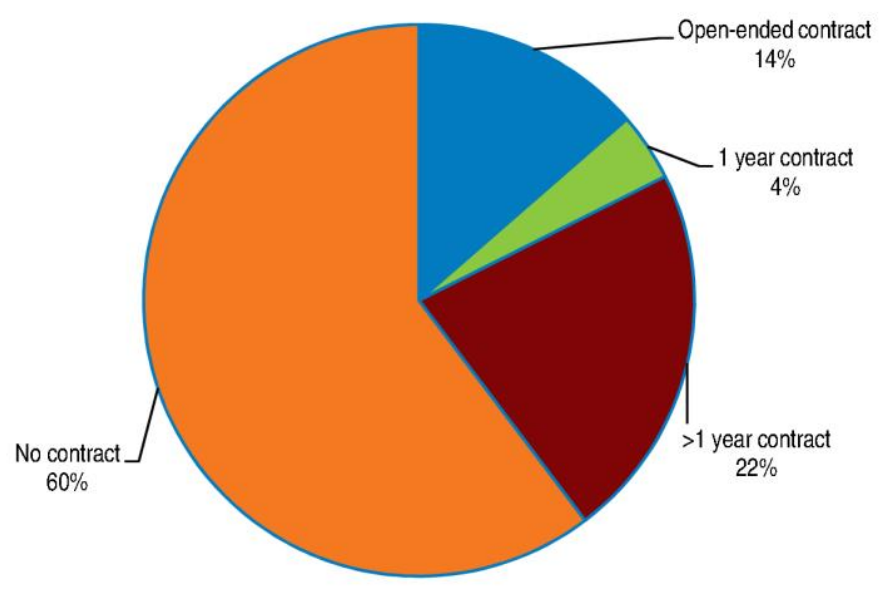

Source: China National Bureau of Statistics.

The low coverage rate of contracts partly reflects employers avoiding social security contributions and their other obligations. However, some workers are also reluctant to make social security contributions due to imperfect portability of benefits (discussed further below) in a context where the vast majority see their move to cities as temporary (OECD, 2015a). In any case, among rural migrants, the existence of a labour contract is associated with obtaining a higher wage (Wang et al., 2015). This suggests that such workers do not trade away employment certainty in return for higher wage benefits.

In general, migrant workers tend to earn a lower wage than those with a local hukou, even in the same job (Zhu, 2016). A significant body of evidence suggests that this partially reflects discrimination that is not related to job performance. While migrants from other urban areas may be afforded a wage premium to compensate for lower social security protection, this does not tend to be the case for rural-to-urban migrants (Gagnon et al., 2014). Such wage discrimination has been found to be particularly pronounced in urban state-owned enterprises (SOEs; Song, 2016).

\section{Box 3. China's migrant workers and hukou system}

In the Chinese context, migrant workers refer to rural workers engaged in non-agricultural activities. By 2016, there were 281.7 million such workers in China. Around $60 \%$ of these moved away from their place of origin, with the remaining $40 \%$ undertaking a non-agricultural job within their local area. In recent years, the number of rural workers living in cities has stagnated (Molnar and Chalaux, 2017).

China's National Bureau of Statistics undertakes an annual survey that sheds light on the characteristics of migrant workers. In 2015, the most recent vintage, around one third of migrant workers were female and the average age of a migrant worker was 38.6 years. Nevertheless, the migrant workforce is gradually ageing. Between 2011 and 2015 , the proportion of migrants aged under 40 declined from $61.7 \%$ to $55.2 \%$.

In 2015, the highest education level of most migrant workers (59.7\%) was junior high school. However, $8.3 \%$ held either a college degree or above. The labour force participation rate of migrant workers has typically been above $95 \%$ 
(Lam et al., 2015) and, in 2015, the majority of these workers were employed in either the construction or manufacturing industry. Nevertheless, the share of migrants employed in secondary industry has declined in recent years, with a greater share taking up jobs in the burgeoning services sector.

A defining feature of China's migration system is the hukou household registration classification. The origins of this policy can be traced back to the Qin Dynasty (Wang and Liu, 2016). However, in modern China, it has mostly been used to govern the distribution of resources and prevent overcrowding in particular locations by limiting population mobility (Wallis, 2016). The system has also served to promote agricultural production, against the backdrop of China's self-sufficiency targets (OECD, 2015a), by managing the outflows of workers from rural areas. Under the hukou system, every Chinese citizen is required to be registered with the hukou authority, with their legal address and various personal details recorded on their registration book. It has typically been difficult for workers who do not possess a local hukou to obtain a variety of public services, notably with respect to education, health care, pension, welfare and affordable housing in their place of residence (OECD, 2015a). While data are only available to 2014, the majority of migrant workers were not covered by social insurance in their destination city at that time (Table 3 ).

Table 3. Migrant workers have limited access to public services in their destination city

In per cent

\begin{tabular}{lcccccc}
\hline & 2009 & 2010 & 2011 & 2012 & 2013 & 2014 \\
\hline Social insurance coverage & & & & & & \\
Pension & 8 & 10 & 14 & 14 & 16 & 17 \\
Industrial injury insurance & 22 & 24 & 24 & 24 & 29 & 26 \\
Medical insurance & 12 & 14 & 17 & 17 & 18 & 18 \\
Unemployment insurance & 4 & 5 & 8 & 8 & 9 & 11 \\
Maternity insurance & 2 & 3 & 6 & 6 & 7 & 8 \\
\hline
\end{tabular}

Source: National Bureau of Statistics.

Under the government's National Urbanisation Plan for 2014-20, a further 100 million rural dwellers will migrate to urban areas by 2020 , raising the urbanisation rate to $60 \%$. In recent years, the government has undertaken a series of reforms to the hukou system to better allow migrant workers to gain residency status, and thereby access to public services, in the cities in which they live. Nevertheless, the conditions for gaining residency status vary greatly between locations and there are still tight restrictions in the most popular destination cities. For example, residency in Beijing and Shanghai is controlled under a stringent points-based system where a migrant worker needs to prove that they i) have possessed legal and stable employment for a certain period ii) live in a legal and stable residential unit and iii) have participated in the city social security system for a certain number of years. In some locations, such as in the prefecturelevel city of Suzhou in Jiangsu province, reforms have instead focused on delinking eligibility for urban public services from hukou status. This has been done by granting resident migrants a residence permit that provides them the same rights as local urban hukou holders (Koen et al., 2013).

\section{Increasing labour market opportunities for women}

China's female participation rate is high. In 2014, around 70\% of females between the ages of 15 and 64 were in the labour force, 4 percentage points higher than the average in the OECD and 16 percentage points higher than the average in BRIICS countries. Nevertheless, between 1990 and 2014, the labour force participation rate of 15-64 year old females declined by 9 percentage points. Compared with trends in the participation rate for men, there has been a particularly steep decline in the participation of women aged 25 to 34 (Dasgupta et al., 2015). This may have partly reflected rapid household income growth, giving females who wished to leave the labour force the financial capacity to do so. However, the declining role of SOEs in the economy has also been associated with a reduction in the de facto provision of legislated parental leave (Shin et al., 2013). Furthermore, there have been significant changes in the public provision of child care which may have negatively impacted female participation rates, especially for some vulnerable groups. This is because domestic duties continue to be largely carried out by females: $38 \%$ of urban unemployed females in 2014 attributed their unemployment to having to prioritise housework compared with $4 \%$ of the male urban unemployed. 
Following reforms to SOEs in the late 1990s, the number of publicly-funded childcare places fell dramatically. Such places for children aged 0-2 years in nurseries no longer exist (Du and Dong, 2013) and the public childcare places for older children mostly benefit parents that are employees of large SOEs or the government (Cook and Dong, 2016). The number of private kindergartens has grown rapidly to fill the void and now significantly exceeds the number of public childcare institutions. However, the fees for such care are often high: in 2015, average annual private kindergarten fees amounted to $30 \%$ of average urban disposable income per capita and around $80 \%$ of average rural disposable income per capita.

The occupational profile of Chinese women in employment is different to that of men. Most notably, the agricultural employment share for women was around 11 percentage points higher than for men in 2014 (Figure 13). The decline in the agricultural employment share between 2006 and 2014 was also slower than for men, reflecting China's "left behind women". These are females in rural areas who are tasked with working on the household farm allocation while their husband temporarily migrates to a higher-paid urban job. Given the government's objective to encourage further rural-to-urban migration, the reallocation of women to urban jobs will be important. However, the typical education level of women currently working in agriculture is substantially lower than that of those working in the jobs typically found in urban areas. Consequently, important changes to land and household registration policies in rural areas (OECD, 2015a) that further encourage the rural-to-urban transition will need to be coupled with policies focused on improving female education.

Figure 13. The employment share in agriculture is higher for women Occupation by gender, 2014

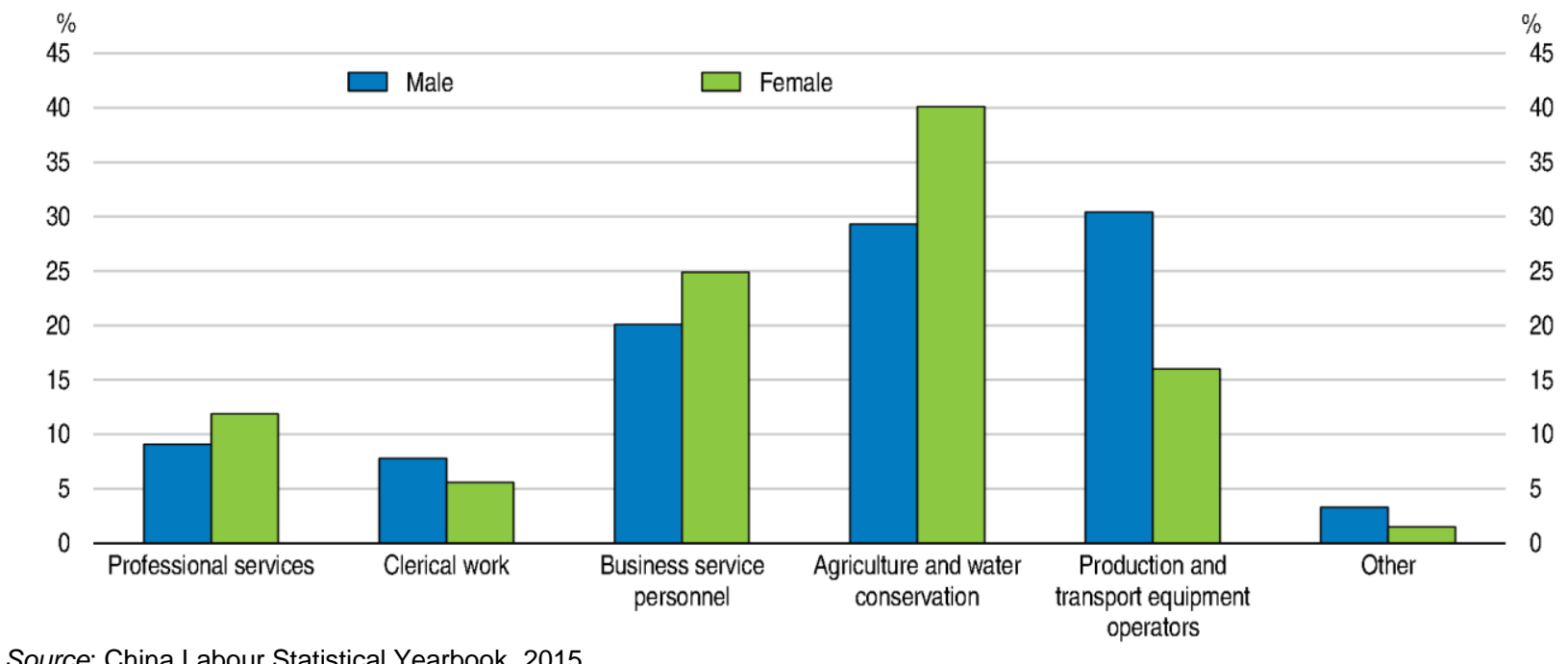

Source: China Labour Statistical Yearbook, 2015.

A wage gap commonly exists between men and women in China which may reduce the incentive for women to seek employment and the wellbeing of those women on low incomes. The share of women in top-management positions in China is below the OECD average (OECD, 2016b). However, a number of studies that use household level data and control for differences in seniority, occupations, locations and worker endowments find that females are paid less than males (Dasgupta et al., 2015; Xiu and Gunderson, 2013; Su and Heshmati, 2011). Focusing on migrant workers, Qin et al. (2016) find that the bulk of the difference in wages between males and females is due to gender discrimination.

Gender equality is gaining more attention with China's policymakers, as highlighted by the Gender Equality and Women's Development White Paper (State Council of China, 2015). However, further efforts are now needed to translate these sentiments into new policy measures. Policy changes that improve the ability of men to care for children and undertake domestic duties, thereby better enabling females to enter 
the labour market, will help. A recent reform in Shanghai that increases childcare leave for new fathers from three to 10 days moves in the right direction. Measures that increase the public provision of childcare or provide subsidies to low-income families using high-quality private childcare providers are also needed (although this will need to be funded by either more tax or social security revenue). Ensuring that there is high female representation in active labour market programmes will assist women to be better-equipped to transition amid ongoing technological upgrading in the industrial sector. At the workplace level, government institutions that identify the need for upward adjustment to female wages where unexplained earning disparities exist and measures that promote gender diversity in leadership positions are vital. An example of the latter may be government support for mentoring and training programmes that are targeted at women.

\section{Improving the health system to enhance living standards}

Life expectancy at birth in China rose by five years between 2000 and 2015, to 76.3 years, thanks to rapid improvements in living standards and public investment in health. Nevertheless, it is expected that a child born in China today will live four years less than one born in the average OECD country. A strong and equitable healthcare system that supports increasing healthy life expectancy is integral to wellbeing and the ability of the population to productively participate in the labour force. It is especially important in China given the rapidly ageing population and the ongoing rebalancing of the economy away from capitalintensive industry to services.

\section{Significant disparities exist in accessing healthcare}

Recent strong growth in China's public health expenditure has been associated with reductions in inequalities across genders, regions and income levels (Gómez, 2015). The number of beds in healthcare institutions has risen from 2.8 per 1000 people in 2007 to 5.1 in 2015. Outpatient care is also being provided through community health centres in some areas. For example, in Zhaoqing city in Guangdong Province, a pilot programme is underway whereby each community health centre doctor is responsible for providing outpatient care at the home of elderly or severely sick people in a catchment area. One constraint to implementing the programme nationwide is shortages of quality healthcare personnel. Even within the hospital system, patients seek higher levels of care in order to access professionals with more expertise (Sun et al., 2015). This leads to higher costs that are ultimately borne by households. Hospital congestion in many large cities has even resulted in the development of informal markets for the appointment tickets required to see a doctor.

Low availability of healthcare personnel is particularly pronounced in rural areas (Figure 14), contributing to child mortality rates that are over double that in urban China. The number of village clinics, which provide basic medical services in rural areas, has even been diminishing. Between 2011 and 2016, the number of village clinics declined by over 20000 (3.2\%). Since 2011, the government has implemented the Rural Compulsory Education Student Nutrition Improvement Plan, which has included the provision of free school meals for students in poverty-stricken rural areas. The standardisation and transparency of this policy has benefited from a programme created by the China Development Research Foundation that uses mobile phone technology to share and monitor the free meal initiative.

Both the nationwide shortage of healthcare professionals and the disparities in personnel between urban and rural areas reflect relative wages. Despite the heavy workload associated with a medical degree, the average monthly income for new doctors in 2014 was around $40 \%$ below that for internet developers (MyCOS, 2015). Within the health sector, wages are lower in rural areas and for professionals who work in primary care (World Bank et al., 2016). Community-based primary care has also been given relatively little emphasis in training programmes for healthcare professionals. This contrasts with the situation in many 
OECD countries, where resources have been increasingly dedicated to improving primary care capacity (World Bank et al., 2016).

Figure 14. The availability of healthcare is much lower in rural areas

Ratio of health professionals per resident between urban and rural areas, 2015

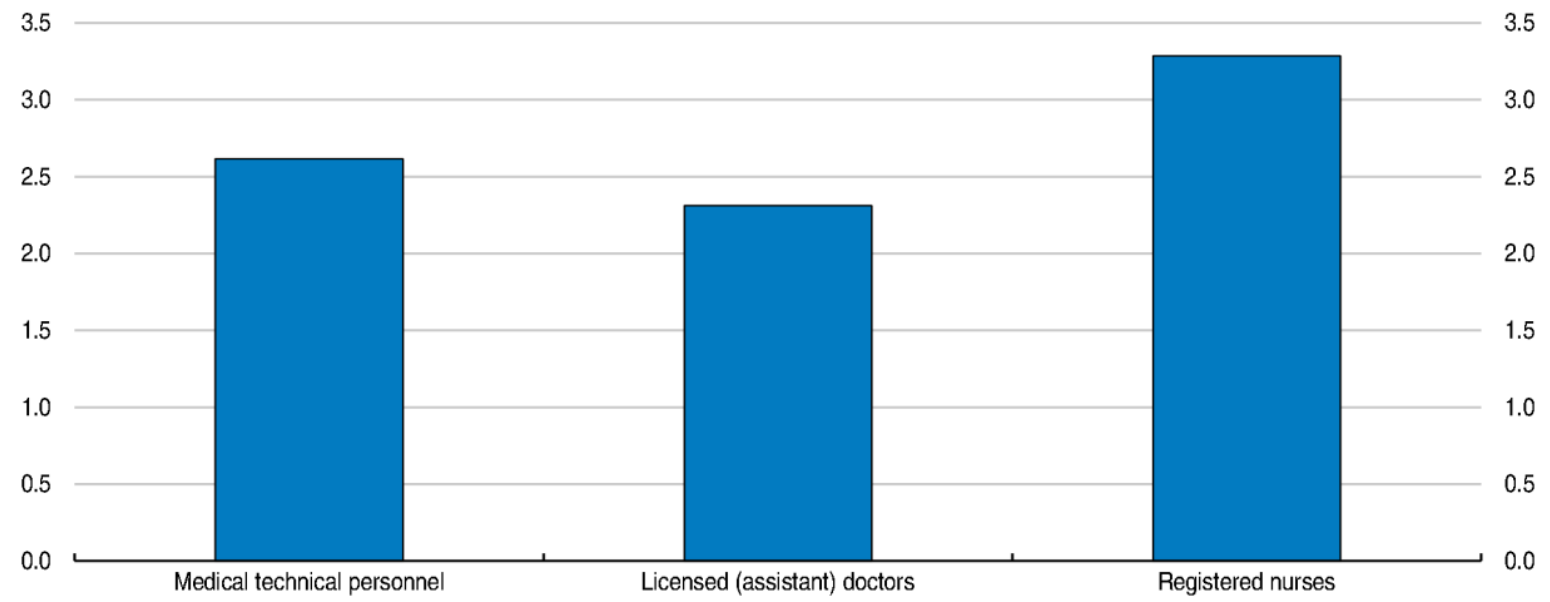

Source: China Statistical Yearbook 2016.

Doctor remuneration is commonly linked to the volume of medicines prescribed or procedures performed, resulting in over-prescription. Indeed, pharmaceutical expenditures per capita far exceed those in the average OECD country. Such practices tend to increase the costs to patients and can threaten their wellbeing. The government has introduced measures in some locations to reduce such abuse, such as the establishment of computer systems that monitor the flow of prescriptions and a zero-profit drug policy which eliminates mark-ups by hospitals on some drugs. Policymakers are also considering ways to increase the salaries of nurses and doctors that do not lead to over-prescription in the public health sector.

One potential channel is for doctors to provide fee-based private services in addition to their standard hospital work. Currently, outside the network of military and police hospitals, doctors cannot lease rooms for such activities. If such services were permitted, it would allow wealthier patients to pay a higher fee to bypass hospital waiting rooms, while allowing lower-income households greater access to health professionals through the public system (provided they can afford the out-of-pocket medical expenses). Nevertheless, such a system would need to be accompanied by a robust evaluation framework for assessing such doctors. Moreover, existing regulations would need to be amended, notably the regulation for licensed medical practitioners, which rigidly dictates the structure and responsibility of the posts of healthcare workers. The government's recent "three medical linkages" policy framework is a step in this direction insofar as it stresses the need for more market-oriented health purchasing mechanisms (Ministry of Human Resources and Social Security, 2016a).

Excessive demand for medical care and the fact that outpatient services are typically not reimbursed by health insurance providers has contributed to a proliferation of unregistered practitioners. Such health providers are either untrained or have qualifications that are not recognised in their place of residence. A study related to such practitioners in Guangzhou highlighted that rural-to-urban migrants are the largest users of such services (Bork-Hüffer and Kraas, 2015). Furthermore, these health providers were not found to emphasise preventive care, worsening the health outcomes and future health costs of an already marginalised group. 


\section{Health insurance system}

Access to healthcare has been improved by an impressive expansion in health insurance coverage. Between 2004 and 2014, the coverage rate rose from around 200 million to over 1.3 billion people - the largest expansion of insurance coverage in human history (Yu, 2015). There are currently three health insurance schemes: i) Urban Employee Basic Medical Insurance, ii) Urban Resident Basic Medical Insurance and iii) the New Rural Cooperative Medical Scheme. It is planned that the latter two will be integrated in the near future. At present, the premiums paid for the urban resident and rural scheme are lower than those for the urban employee scheme. This translates into disparities in benefits which may put sick rural or urban residents at a disadvantage relative to urban employees.

Overall, out-of-pocket payments have declined in recent years owing to increases in government subsidies. Nevertheless, by international standards, direct health outlays by households remained high in 2015 (Figure 15). In December 2016, the State Council published the 13th Five Year Plan objectives for the medical and health system. These included a reduction in out-of-pocket health costs as a share of total health expenditure to $28 \%$ (from $29.3 \%$ in 2015) and basic health insurance coverage for $90 \%$ of the population by 2020 . Some studies have found that being covered by the urban resident insurance system increases healthcare utilisation but does not reduce out-of-pocket payments (Liu et al., 2014; Liu and Zhao, 2014). To what extent this reflects patient choice or over-prescription is unclear. To reduce the risk of the latter, a shift from a reimbursement system dominated by fee-for-service payments to one where payments from insurers are not contingent on the volume of services provided (e.g. capitation or diagnosis-related group payments) should be considered. So too should be measures that more closely link insurance payments to the quality of services provided.

Figure 15. Out-of-pocket health costs for the insured are high

As a percentage of total health expenditure (\%), 2015 or latest available

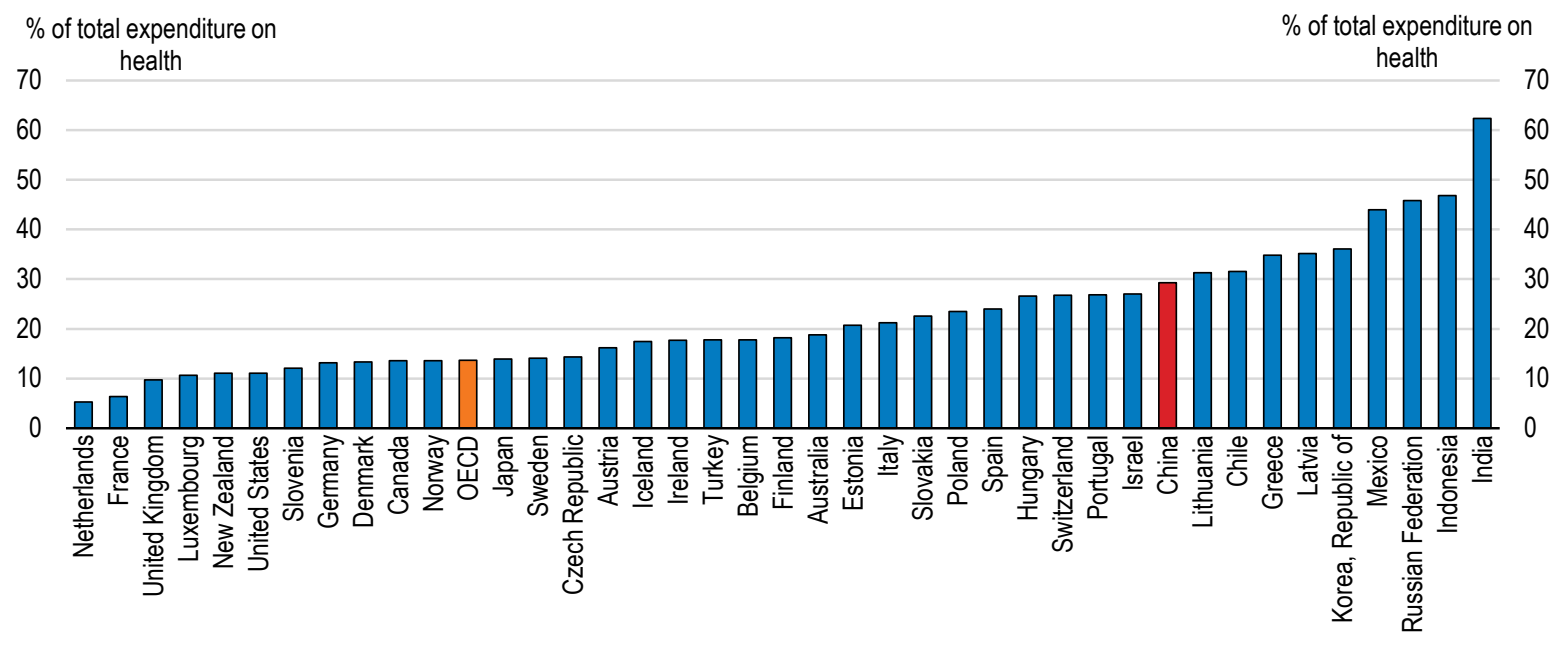

Note: Data relate to 2015 for China and to 2014 for all other countries.

Source: World Health Organization Global Expenditure Database, China Statistical Yearbook 2016.

Families living below the dibao minimum income threshold, or those who can show their livelihoods have been severely affected by unexpectedly high medical costs, can receive government assistance. This either takes the form of subsidies for insurance premiums or medical financial assistance cash transfers. Nevertheless, the analysis in Box 2 suggests that those living below the poverty line generally spent a higher share of their income on medical expenses than those not living in poverty in 2014. Continued 
improvement in the targeting of medical financial assistance and further efforts to reduce out-of-pocket payments are needed to reduce financial strains on such groups.

In 2014, only $18 \%$ of migrant workers were covered by medical insurance from an employee scheme. At that time, all other migrant workers were required to return to their place of origin to claim health insurance benefits through the New Rural Cooperative Medical Scheme. Increasingly, reforms have enabled reimbursement at the place of residence if a migrant worker originates from the same province. For example, in recent years, health costs incurred in Hohhot, the capital city of Inner Mongolia, have been reimbursed regardless of the location of the individual's hukou within the province. In December 2016, the government announced that patients will be able to claim reimbursement in the location of the treatment regardless of which health insurance scheme they belong to or the province from which they come (Ministry of Human Resources and Social Security, 2016b). This reform should improve the utilisation of health services by migrant workers and reduce the time between when health costs are incurred and reimbursed.

\section{Further policy measures are needed to combat air pollution}

The detrimental health effects of air pollution continue to be a major concern. Stroke, heart disease, lung cancer and respiratory diseases can all be caused by high levels of ambient air pollution. Such health effects impede the ability of victims to participate in the economy and to lead a happy life. Health problems associated with pollution can have disproportionately large impacts on the poor, who may suffer greater exposure to pollution and have fewer options to relocate (OECD, 2013). Furthermore, exposure in less developed industrial provinces such as Henan is considerably greater than in some other areas that have transitioned to a more services-based economy.

There were an estimated 670 premature deaths per million people in China from exposure to particulate matter and ozone concentrations in 2010 (OECD, 2016c). In recent years, while air pollution has remained at dangerous levels, concentrations in some locations have moderated. This may have been due to the implementation of the tougher penalties for polluting businesses outlined in the Environmental Protection Law of 2015, as well as stricter standards for the sulphur content of motor fuel. Nevertheless, the number of pollution-related deaths per capita is expected to increase substantially over the period to 2060 in the absence of further government policy interventions (OECD, 2016c). There are plans to launch a national emissions trading scheme in 2017, which will reduce the types of pollution harmful for health if implemented effectively.

The main sources of air pollution in China include coal combustion, transport and agricultural waste burning. Improvements in the provision of public transport and the urban design of China's biggest cities should reduce pollution levels. Developing more compact cities can enable shorter commuting distances, better energy efficiency in buildings and a better use of land resources (OECD, 2013), according with several of the United Nations Sustainable Development Goals. This can be achieved through urban planning policies that move away from developing the "superblocks" (blocks of property organised around an arterial grid of roads that tend to be both very wide and very far apart) that exist in many Chinese cities and which tend to favour private automobile transport (OECD, 2015c). Pollution from transport may also be cut by eliminating subsidies for fossil fuels. Furthermore, recent OECD simulations suggest that replacing fuel subsidies with cash transfers can mitigate potential regressive effects and reduce poverty (Durand-Lasserve et al., 2015).

To reduce pollution from the burning of agricultural waste, improvements in the skills and technologies used in the agricultural sector are needed. China's network of agricultural extension agents should be mobilised to communicate and teach new burning strategies and methods of waste disposal. 
These may include crop rotation strategies and techniques for turning agricultural waste into biofuels. Better training for farmers may also help reduce soil pollution, given that it is often linked to the overuse of nitrogen fertilisers (OECD, 2015a). Water pollution is also at dangerously high levels in many parts of China, affecting health and wellbeing. The Environmental Protection Tax Law, passed in December 2016 and effective from January 2018, mandates the collection of taxes on water and air pollutants as well as on solid waste and noise, and is a welcome step in the right direction.

\section{Tobacco consumption is high and obesity is rising}

High levels of tobacco consumption continue to jeopardise the health of the male population, but recent policy changes seem to be reducing smoking rates. Smoking can lead to many of the same noncommunicable diseases that derive from high air pollution exposure, reducing labour force participation and weighing on the health system. While the smoking rate for women in China is very low, a much higher proportion of men smoke than in the average OECD country. Cigarette consumption per capita rose sharply through the 2000s as smoking became more affordable (OECD, 2010). As at 2012, around half of men above the age of 15 were smokers (OECD, 2015d).

In 2015, Chinese tobacco consumption fell for the first time since 1995. This coincided with the government implementing several policy measures that accorded with past OECD recommendations (OECD, 2010). Indoor smoking was banned, with fines levied on both individual violators as well as businesses failing to enforce the law on their premises. Restrictions on tobacco advertising were also imposed and the wholesale consumption tax was increased from $5 \%$ to $11 \%$, which translated into higher retail prices. Nevertheless, the tax portion of the retail price of packet of cigarettes remains low in China compared with other countries (Zheng, 2016). Further increases in tobacco tax rates should thus be considered to promote healthy lives.

Obesity has also become a major concern for the health system. Nationwide, the rate of obesity is lower than in some other emerging economies (Burgraff et al., 2015), but it is rising rapidly, especially in urban areas. This has partly reflected transitions to a higher-calorie diet and a more sedentary lifestyle with the change in industrial structure and rapid income growth of the past few decades. Higher obesity raises the risk of acute and chronic diseases such as heart disease, stroke, Type 2 diabetes and hypertension, increasing costs for China's health system (Qin and Pan, 2016). However, previous work has highlighted policy packages including mass media campaigns, food taxes and subsidies, nutritional labelling and market restrictions that would result in substantial reductions in obesity levels. Furthermore, the cost of such a package would be relatively low in China compared with some other middle-income countries (Cecchini et al., 2010).

\section{Extending the working lives of the elderly and caring for them in retirement}

Improvements in the health system will be important for ensuring China's elderly population can live long active lives and be cared for in their later years. So will government policies supporting old-age participation in the labour market and the sustainability and adequacy of the pension system. These priorities are gaining prominence as China's population ages.

Along with the other facets of China's social welfare framework, the pension system has developed substantially over the past few decades. Before 1997, the only pension payments were provided by China's SOEs and were funded without regular contributions. Since that time, new funded schemes have been established for urban employees, urban and rural residents and for civil servants and public service unit employees. Over $90 \%$ of people with pension contributions belong to either the urban employee or urban 
and rural resident schemes. Nevertheless, pensions are administered at the local level within each of the schemes, leading to a high degree of fragmentation in the system.

The government is aiming for universal pension coverage by 2020. However, enrolment of migrant workers is low, with only $17 \%$ of them affiliated to a scheme in their place of employment in 2014. While the urban employee scheme is meant to be compulsory, some businesses offer migrant workers higher wages if the payments go undeclared so that they do not have to make employer social security contributions (World Bank and DRC, 2014). Furthermore, both those migrant workers who have labour contracts and those who do not may be discouraged from enrolling in a pension scheme due to poor benefit portability between regions. According to guidance from the central government, a migrant worker should retain the rights to their accrued pension benefits if they move back to their rural home or to another city. However, there is currently no centralised record-keeping system, with each local government applying their own administrative arrangements. Consequently, in practice, it is difficult for pension benefits to be transferred.

Benefits vary substantially across and within the pension schemes, which may stoke inequalities at older ages. Benefits under the resident scheme are generally lower, owing to low individual contributions. Residents must contribute only CNY 100 per year to be eligible for the basic pension, with the returns on excess contributions set at the one-year bank deposit rate (which is currently below $2 \%$ ). There is also a component of resident pension contributions that is matched by local governments. However, in poorer regions, the matched amount is set low as it is funded from local government revenues. In contrast to the resident scheme, replacement rates under the urban employee and civil servant schemes compare favourably with those in the average OECD country (Queisser and $\mathrm{Hu}, 2016$ ).

An emerging issue is the sustainability of China's urban employee pension scheme. Employers contribute $20 \%$ of the individual's wages to a "social pooling" account and workers contribute $8 \%$ of wages to an individual account. Employer contributions are pooled at the local level to finance current benefits along a defined schedule, while employee contributions are meant to be deposited into their individual accounts. However, in recent years, insufficient funds in the social pooling accounts have led local governments to borrow from the individual accounts to fund current payments. This undermines the confidence of households that their pension benefits will be available upon retirement, contributing to high precautionary saving rates.

To make up the current shortfall in pension accounts, a coalition of government ministries has developed a plan to transfer CNY 4-5 trillion of equity from SOEs to the National Social Security Fund (NSSF) between 2017 and the end of 2019. The central government is also now allowing local governments to invest a portion of their pension funds in riskier assets with higher average returns, such as the equity market. This is facilitated by locally-pooled funds being transferred to the NSSF. Nevertheless, parametric adjustments are needed to ensure the long-term sustainability of the scheme.

One such adjustment is an increase in China's relatively low pension age, as underlined in the 2010 OECD Economic Survey of China (OECD, 2010). This is especially the case for women. At present, the normal pension age in China is 60 years for men, 55 for women in white collar jobs and 50 for women in blue collar occupations (Figure 16). Nevertheless, it may be difficult for the government to increase the retirement age when workers are unconvinced that an extra year of work will entitle them to a higher pension benefit. This suggests multiple complementary strategies are warranted, including the equity injections discussed above, to improve the overall sustainability of the pension system.

As well as improving the durability of pension schemes, an increase in the pension age and indexation to life expectancy is advisable to lean against the economic pressures of the ageing population. At the same time, the pension age of men and women should be aligned. These changes need to be coupled with 
regulations that encourage lifelong learning at later ages and stricter monitoring and punishment of age discrimination in the labour market.

Figure 16. The retirement age remains low

Normal pension age, 2015

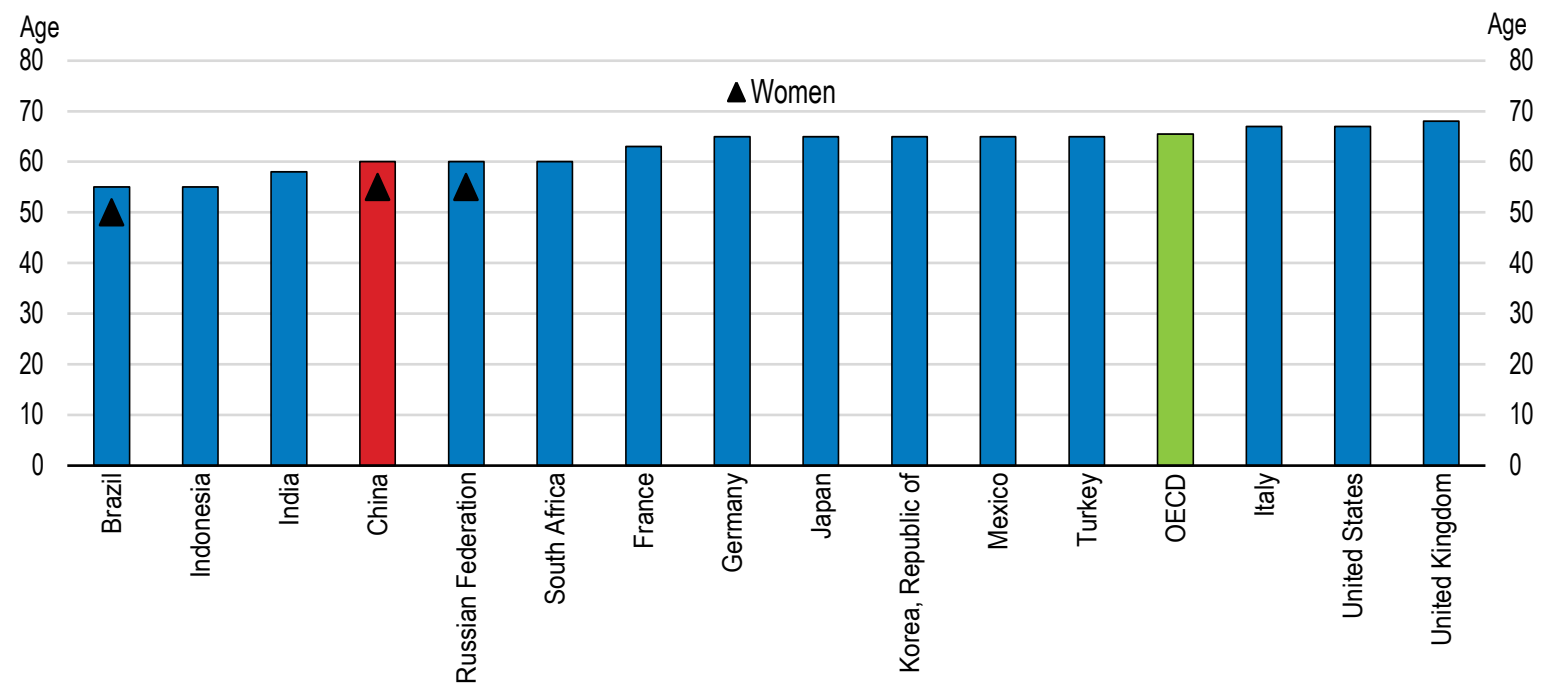

Note: The marker indicates where the pensionable age is lower for women than for men. For China, the marker is for female white collar workers.

Source: OECD (2016), Pensions at a Glance.

In addition to pension payments, there are also some in-kind benefits provided by the government to pensioners and pilot schemes have been launched to assess the feasibility of providing medical insurance for long-term nursing care. Currently, in-kind benefits include reimbursements for various care services provided in the home. However, there is no financial support for family caregivers who need to reduce their wage-earning hours in order to care for a family member. Such a measure is advisable given that, partly as a legacy of the One Child Policy, it is becoming more common that one child must look after two parents and four grandparents.

\section{Recommendations for sharing the benefits of growth by providing opportunities to all}

\section{Key recommendations}

- Base social security contributions on actual income earned.

- Increase central and provincial government social assistance transfers to poorer areas.

- $\quad$ Broaden the personal income tax base and increase tax progressivity.

- Implement a broad-based nationwide recurrent tax on immovable property and consider an inheritance tax that would include some basic inheritance allowance.

- Gradually increase and unify the pension age to 65 and then index it to life expectancy.

- Improve administrative procedures to make it easier to draw a pension in a different location from where it is earned. 
- Increase public funding for childcare and introduce incentives to encourage the participation of migrant children and those in rural areas in early childhood education.

\section{Further recommendations}

\section{Enhancing the redistributive impact of the tax and transfer system}

- Eliminate tax exemptions for interest income and reduce the personal income tax allowance.

- Exclude a portion of any increase in household salary as assessable family income for calculating the dibao benefit for a defined period.

- Increase the level of unemployment benefits through central government financing.

\section{Improving health}

- Allow doctors to rent rooms in public hospitals so they can provide fee-based medical services outside of their standard work.

- Increase the resources devoted to detecting unregistered doctors and the punishment for those caught.

- Focus on improving the provision of public transport and agricultural extension services in the areas that have the highest air pollution from transport and where agricultural waste is burnt on a large scale.

\section{Other reforms to better share the benefits of growth}

- $\quad$ Raise the minimum wage in those areas where the ratio to average wages is relatively low.

- Introduce regulations that require rural teachers to undertake a certain number of training days each year. 
ECO/WKP(2017)41

\section{REFERENCES}

Adalet McGowan, M. and D. Andrews (2015), "Skill mismatch and public policy in OECD countries", OECD Economics Department Working Papers, No. 1210, OECD Publishing.

Bork-Hüffer, T. and F. Kraas (2015), "Health care disparities in megaurban China: The ambivalent role of unregistered practitioners", Tijdschrift voor Economische en Sociale Geografie, Vol. 106, No. 3.

Brandt, L. and C.A. Holz (2006), "Spatial price differences in China: Estimates and implications", Economic Development and Cultural Change, Vol. 55, No. 1.

Brys, B. et al. (2016), "Tax design for inclusive economic growth", OECD Taxation Working Papers, No. 26, OECD Publishing, Paris.

Brys, B. et al. (2013), "Tax policy and tax reform in the People's Republic of China", OECD Taxation Working Papers, No. 18, OECD Publishing, Paris.

Burgraff, C. et al. (2015), "Nutrition transition in two emerging countries: a comparison between China and Russia", International Association of Agricultural Economists Conference 2015, Italy.

Campbell, F. et al. (2014), "Early childhood investments substantially boost adult health", Science, No. 343.

Cecchini, M. et al. (2010), "Tackling of unhealthy diets, physical inactivity, and obesity: health effects and cost-effectiveness", Lancet, No. 376.

Central People's Government of the People's Republic of China (CPGPRC) (2011), China Rural Poverty Alleviation and Development Programme (2011-20).

Cevik, S. and C. Correa-Caro (2015), "Growing (un)equal: fiscal policy and income inequality in China and BRIC+", IMF Working Paper, No. 15/68.

Chateau, J., R. Dellink and E. Lanzi (2014), “An overview of the OECD ENV-Linkages model: version 3”, OECD Environment Working Papers, No. 65, OECD Publishing, Paris.

Chen, L.J. et al. (2015), Report on the State of Children in China, Chapin Hall at the University of Chicago.

China Internet Network Center (2016), Report of China Internet Development Statistics.

Cingano, F. (2014), "Trends in income inequality and its impact on economic growth", OECD Social, Employment and Migration Working Papers, No. 163, OECD Publishing.

Cook, S. and X. Dong (2016), "Gender, welfare and the economy of care in reform era China: How the welfare system shapes women's opportunities and gender equality", Chapter 15 in Handbook of Welfare in China, forthcoming.

Dasgupta, S., M. Matsumoto and C. Xia (2015), "Women in the labour market in China", International Labour Organization Asia-Pacific Working Paper Series, May.

Ding, H. and H. He (2016), "A tale of transition: an empirical analysis of economic inequality in urban China, 1986-2009”, IMF Working Paper, No. 239. 
Du, F. and X. Dong (2013), "Women's employment and child care choices in urban China during the economic transition", Economic Development and Cultural Change, Vol. 62, No. 1.

Durand-Lasserve, O. et al. (2015), "Modelling of distributional impacts of energy subsidy reforms: an illustration with Indonesia", OECD Environment Working Papers, No. 86, OECD Publishing.

Easterlin, R.A. et al. (2013), “China's life satisfaction, 1990-2010”, IZA Discussion Paper, No. 7196.

Fang, L. et al. (2016), "Acculturation, economic stress, social relationships and school satisfaction among migrant children in urban China”, Journal of Happiness Studies, Vol. 17, No. 2.

Fang, T. and C. Lin (2013), "Minimum wages and employment in China", IZA Discussion Paper, No. 7813.

Gagnon, J., T. Xenogiani and C. Xing (2014), "Are migrants discriminated against in Chinese urban labour markets?”, IZA Journal of Labor \& Development, Vol. 3, No. 17.

Gao, Q., S. Yang and S. Li (2015), "Welfare, targeting, and anti-poverty effectiveness: the case of urban China", The Quarterly Review of Economics and Finance, No. 56.

Golan, J., T. Sicular and N. Umapathi (2015), "Unconditional cash transfers in China: an analysis of the Rural Minimum Living Standard Guarantee Program”, Policy Research Working Paper, No. 7374, World Bank.

Gómez, E.J. (2015), "Health spending and inequality in the emerging economies: India, China, Russia and Indonesia in comparative perspective", Oxfam Civil Society Network.

Gong, S. (2013), "Inequality in China: a case study", Save the Children, January.

Guan, X. (2016), "Significance of the minimum income standard and problems of the current standard" (in Chinese), Jiangsu Social Sciences, No. 3.

Huang, Y. (2015), "Bolstering inclusionary housing in Chinese cities", Paulson Policy Memorandum, The Paulson Institute.

Immervoll, H. and M. Pearson (2009), “A good time for making work pay? Taking stock of in-work benefits and related measures across the OECD", OECD Social, Employment and Migration Working Papers, No. 81, OECD Publishing.

Koen, V. et al. (2013), "Policies for inclusive urbanisation in China", OECD Economics Department Working Papers, No. 1090, OECD Publishing.

Lam, W.R. and P. Wingender (2015), "China: How can revenue reforms contribute to inclusive and sustainable growth?”, IMF Working Paper, No. 15/66.

Lam, R. et al. (2015), "China's labour market in the new normal”, IMF Working Paper, No. 15/151.

Leung, J.C.B. and M. Xiao (2015), "The institutionalisation of social assistance”, in Ngok, K and C.K. Chan (eds), China's Social Policy: Transformation and Challenges, Routledge.

Li, C. and J. Gibson (2013), "Rising regional inequality in China: Fact or artifact?", World Development, Vol. 47. 
Lin, C. and M. Yun (2015), "The effects of the minimum wage on earnings inequality: Evidence from China", IZA Discussion Paper Series, No. 9715.

Liu, K., Q. Wu and J. Liu (2014), "Examining the association between social health insurance participation and patients' out-of-pocket payments in China: The role of institutional arrangement", Social Science and Medicine, No. 113.

Liu, H. and Z. Zhao (2014), "Does health insurance matter? Evidence from China's Urban Resident Basic Medical Insurance", Journal of Comparative Economics, No. 42.

Milanovic, B. (2016), Global Inequality: A New Approach for the Age of Globalization, Harvard University Press.

Ministry of Human Resources and Social Security (2016a), Guidance on the Joint Reform of the Medical, Healthcare and Pharmaceutical System, June.

Ministry of Human Resources and Social Security (2016b), Cross-province issues relating to basic medical insurance, including the direct settlement of medical and hospitalised expenses, December.

Ministry of Civil Affairs (MCA) (2014), Interim Measures for Social Assistance, February.

Ministry of Education (2010), Outline of China's National Plan for Medium and Long-term Education Reform and Development 2010-2020.

Molnar, M. (2017), "Boosting firm dynamism and performance in China", OECD Economics Department Working Papers, No. 1408, OECD Publishing.

Molnar, M. and T. Chalaux (2017), "Household consumption in China", OECD Economics Department Working Paper, forthcoming.

Molnar, M. and V. Koen (2015), "Providing the right skills to all in China: From "made in China" to "created in China"”, OECD Economics Department Working Papers, No. 1219, OECD Publishing.

MyCOS (2015), Chinese College Graduates Employment Report, Beijing.

OECD (2016a), Education at a Glance 2016: OECD Indicators, OECD Publishing, Paris.

OECD (2016b), OECD Employment Outlook 2016, OECD Publishing, Paris.

OECD (2016c), The Economic Consequences of Outdoor Air Pollution, OECD Publishing, Paris.

OECD (2015a), OECD Economic Surveys: China 2015, OECD Publishing, Paris.

OECD (2015b), OECD Employment Outlook 2015, OECD Publishing, Paris.

OECD (2015c), OECD Urban Policy Reviews: China 2015, OECD Publishing, Paris.

OECD (2015d), Health at a Glance 2015, OECD Publishing, Paris.

OECD (2014), OECD Employment Outlook 2014, OECD Publishing, Paris.

OECD (2013), OECD Economic Surveys: China 2013, OECD Publishing, Paris. 
OECD (2011), "The taxation of low-income workers", Taxation and Employment, OECD Publishing. Paris.

OECD (2010), OECD Economic Surveys: China 2010, OECD Publishing, Paris.

OECD/IDB/WAPES (2016), The World of Public Employment Services: Challenges, capacity and outlook for public employment services in the new world of work, IDB, Washington, D.C.

Peng, W.J. et al. (2014), "Emerging perceptions of teacher quality and teacher development in China", International Journal of Educational Development, No. 34.

Peking University (2014), China Welfare Development Report, Institute of Social Science Survey.

Qian, J. and K.H. Mok (2016), "Dual decentralization and fragmented authoritarianism in governance: crowding out among social programmes in China", Public Administration and Development, No. 36.

Qin, M. et al. (2016), "Gender inequalities in employment and wage-earning among internal migrants in Chinese cities", Demographic Research, Vol. 34, No. 6.

Qin, X. and J. Pan (2016), "The medical cost attributable to obesity and overweight in China: estimation based on longitudinal surveys", Health Economics, Vol. 25, No. 10.

Queisser, M. and Y. Hu (2016), "China pension system and reform - An OECD perspective”, mimeo.

Ravallion, M. and S. Chen (2015), "Benefit incidence with incentive effects, measurement errors and latent heterogeneity: A case study for China", Journal of Public Economics, Vol. 128.

Salvi del Pero, A. et al. (2016), "Policies to promote access to good-quality affordable housing in OECD countries", OECD Social, Employment and Migration Working Papers, No. 176, OECD Publishing, Paris.

Shi, Y. et al. (2016), "Effects of parental migration on mental health of left-behind children: evidence from Northwestern China", China \& World Economy, Vol. 24, No. 3.

Shi, Y. et al. (2015), "Dropping out of rural China's secondary schools: a mixed-methods analysis", The China Quarterly, Vol. 224.

Shin, Y. et al. (2013), "Comparative study of family policy in East Asia", Korea Institute for Health and Social Affairs Policy Report, No. 76.

Solt, F. (2016), “The Standardized World Income Inequality Database”, Social Science Quarterly, No. 97.

Song, Y. (2016), "Hukou-based labour market discrimination and ownership structure in urban China", Urban Studies, Vol. 53, No. 8.

State Administration of Taxation (2016), Non-resident financial accounts tax-related due diligence information management approach (draft), 28 October.

State Council of China (2016a), Solving the registration of people without residence cards.

State Council of China (2016b), Opinion on promoting the integration of overall reform and development of urban and rural compulsory education in the county.

State Council of China (2015), Gender equality and women's development in China.

$\mathrm{Su}$, B. and A. Heshmati (2011), "Analysis of gender wage differential in China's urban labor market", Institute for the Study of Labor Discussion Paper, No. 6252. 
Sun, Z., S. Wang and S. Barnes (2015), "Understanding congestion in China's medical market: an incentive structure perspective", Health Policy and Planning, Vol. 1, No. 14.

Wallis, C. (2016), “Hukou reform and China’s migrant workers”, China Policy Institute, October.

Wang, F. and Y. Liu (2016), "Interpreting Chinese Hukou system from a Foucauldian perspective", Urban Policy and Research.

Wang, H., F. Guo and Z. Cheng (2015), "A distributional analysis of wage discrimination against migrant workers in China's urban labour market”, Urban Studies, Vol. 52, No. 13.

Westmore, B (2017), "Do government transfers reduce poverty in China? Micro evidence from five regions", OECD Economics Department Working Papers, forthcoming.

Wilmsen, B. and M.Y. Wang (2015), "Voluntary and involuntary resettlement in China: a false dichotomy?", Development in Practice, Vol. 25, No. 5.

World Bank et al. (2016), Deepening health reform in China: building high-quality and value-based service delivery, World Bank Group.

World Bank and Development Research Center of the State Council (DRC) (2014), Urban China: Toward Efficient, Inclusive and Sustainable Urbanization, Washington D.C.

Xie, Y. and Y. Jin (2015), "Household wealth in China”, Chinese Sociological Review, Vol. 47, No. 3.

Xing, C. and J. Xu (2016), "Regional variation of the minimum wages in China", IZA Journal of Labor \& Development, Vol. 5, No. 8.

Xiu, L. and M. Gunderson (2015), "Occupational segregation and the gender earnings gap in China: devil in the details", International Journal of Manpower, Vol. 36, No. 5.

Xu, D. and X. Wu (2016), "Separate and unequal: hukou, school segregation, and migrant children's education in urban China", Population Studies Center Research Report, No. 16-586.

Yang, J., X. Huang and X. Liu (2014), “An analysis of education inequality in China”, International Journal of Educational Development, Vol. 37.

Yu, H. (2015), "Universal health insurance coverage for 1.3 billion people: What accounts for China's success?", Health Policy, No. 119.

Zhang, C. et al. (2014), "Are poverty rates underestimated in China? New evidence from four recent surveys", China Economic Review, No. 31.

Zheng, R. (2016), "2015 Tax Reform in China: Results and Challenges", Presentation at Winning the Tax Wars Conference, World Bank, Washington D.C.

Zhu, R. (2016), "Wage differentials between urban residents and rural migrants in urban China during 2002-2007: A distributional analysis", China Economic Review, No. 37. 